\title{
Is There a J-Curve Effect in Sierra Leone? An Empirical Analysis with VECM
}

\author{
Emerson Abraham Jackson, Edmund Tamuke, Abdulai Sillah \\ Research Department, Bank of Sierra Leone, Freetown, Sierra Leone \\ Email: ejackson1@bsl.gov.sl, emersonjackson69@gmail.com, etamuke@bsl.gov.sl, edmundectamuke845@gmail.com, \\ asillah@bsl.gov.sl
}

How to cite this paper: Jackson, E. A., Tamuke, E., \& Sillah, A. (2021). Is There a J-Curve Effect in Sierra Leone? An Empirical Analysis with VECM. Modern Economy, 12, 1486-1518.

https://doi.org/10.4236/me.2021.1210076

Received: August 8, 2021

Accepted: October 26, 2021

Published: October 29, 2021

Copyright $\odot 2021$ by author(s) and Scientific Research Publishing Inc. This work is licensed under the Creative Commons Attribution International License (CC BY 4.0).

http://creativecommons.org/licenses/by/4.0/

\begin{abstract}
This paper examines the relationship between exchange rate and trade balance in determining whether the J-Curve phenomenon holds in the short and long-run for Sierra Leone during the period 2002Q2-2019Q4. The econometric technique commenced with an assessment of unit root to ascertain the order of Unit Root and followed by an Unrestricted Vector Autoregressive (VAR) estimation. The procedure leading to using Vector Error Correction Model (VECM) was confirmed through Johansen Cointegration test. The result suggests long-run relationship running between exchange rate and trade balance for all three model equations, but weakly for the Trade Balance Model, which is also attested in the impulse response shock for trade balance and real effective exchange rate. The Marshall-Lerner (ML) condition was also satisfied, with the joint elasticity for Export and Import summing up to more than one. The short-run dynamic situation for Sierra Leone was not satisfied with the Wald Tests for all three models-this could be due to internal macroeconomic bottlenecks associated with weaknesses in the real sector. The findings for this study are relevant for Central Bank policy formulation and fiscal consolidation efforts. It is highly recommended that domestic production is boosted to ascertain macroeconomic stability in the economy.
\end{abstract}

\section{Keywords}

VECM, J-Curve, ML Condition, Trade Balance, Exchange Rate, Sierra Leone

\section{Introduction}

J-Curve effect is modelled on the assumption that a country's trade balance initially worsens following a devaluation of its currency exchange rate-there is also a possibility of recovery with an outcome that surpasses its previous performance (Rose \& Yellen, 1989). In this vein, the concept implies that deprecia- 
tion in exchange rate will stimulate a country's exports at international market prices, which in effect will increase demand for its exports by consumers overseas due to the fact that such goods will be sold out cheaply in the foreign market (Bawa et al., 2018). On a similar note, depreciation will also raise domestic prices of imports, thereby rendering imports more expensive, thereby resulting in decrease demand for imports on account of consumers switching habit formation towards locally produced goods and services, more with inelastic traded goods and services. In the short run, increase demand for a country's exports, will eventually result in exchange rate depreciation, while a subsequent fall in demand for high costly imported goods will ultimately improve a country's terms of trade (under ceteris condition).

Plethora of studies have been pursued in ascertaining the reality of J-Curve and Marshall-Lerner condition in a bid to determine relationship between a country's exchange rate and trade balance, with some notable highlights for the Sierra Leone economy (Lerner, 1944; Bangura et al., 2013; Adeniyi et al., 2011). Critical to such pursued efforts, stability in a country's exchange rate is very important in determining currency valuation, particularly in building favourable terms of trade, which is essential for maintaining stable macroeconomic condition (Bangura et al., 2013). Many a time, countries may decide to adopt a particular exchange rate regime (flexible/floating, fixed or a mixture of both) on the premise of achieving macroeconomic stability.

Since independence, Sierra Leone has walked through the path of a "flexible" exchange rate system, but such approach is still not bringing the desired goal due to structural bottlenecks connected with internal macroeconomic instability (e.g., an almost two-decades of civil unrest in the early 1990s to 2000, and more recently Ebola in 2014, Mudslide in 2017 and COVID-19 pandemic in 2020). Exchange rate mechanism is a worthwhile concept that helps a country determine its competitiveness with the rest of world. In Sierra Leone, tremendous efforts are continuously utilised by the central bank to dampen concerns connected with inflationary pressure given weaknesses connected with the real sector (Tamuke et al., 2018; Jackson, 2020a). Increase consumption pattern by agents in the domestic economy to consume more of imported (inelastic) goods and services is highly to be blamed for the country's continued crises in the forex market (Jackson \& Jabbie, 2020a).

Over the years, the Leone currency has witnessed series of devaluation in a bid to stabilise the economy, which also have some implications for international competitiveness (Bangura et al., 2013). Despite these concerns, there has been some favourable terms of trade, even in the aftermath of the Organisation of African Unity (OAU) summit—notable highlight includes an improvement in deficit from " $-11.0 \%$ to a surplus of $4.90 \%$ between 1980-1984" (Bangura et al., 2013). During the period of Iron Ore boom (2013-2014), the country was highly profiled, with a favourable term of export-led growth, which also recorded surpluses in the balance of trade account-the outcome of such surpluses also featured Si- 
erra Leone as one of the fastest growing economies in the Sub-Saharan African region, which was only short-lived (SSL, 2014).

The motivation for this study is to support effective policy formulation at the Bank of Sierra Leone, through empirically pursued effort in assessing long and short-run relationship between exchange rate and trade balance. The outcome of this study will prove beneficial to policy makers in terms of assessing the dynamics of selected dependent indicators considered relevant in addressing linkages between exchange rate and Trade Balance, both in the short and long-run. The outcome of this research will also add value to earlier work pursued by Bangura et al. (2013), which will enable policy makers to make informed judgment(s) about the effectiveness of policy measures in dampening concerns around exchange rate and trade balance in Sierra Leone-this also have implications in combatting supply-side driven inflation crises and its pass-through effect to consumers in the domestic economy (see Bangura, Caulker, \& Pessima, 2012; Jackson, Tamuke, Jabbie, \& Ngombu, 2020).

In pursuance of the researchers' quest for exploring an answer to the country's continued exchange rate depreciation crises and deficit in the trade balance (directly linked with the concept of the J-Curve effect), we have poised to set ourselves on the journey of answering the following research question: Does the J-Curve phenomenon hold with reference to Sierra Leone's volatile exchange rate dynamics and trade balance?

In order to answer the above research question pertaining to the existence of J-Curve effect in Sierra Leone, the objectives of the study therefore includes: 1) To assess whether the J-Curve phenomenon holds in Sierra Leone, both in the short and long-run; 2) To examine the robustness of the relationship between exchange rate and trade balance by applying the Marshall-Lerner condition; and 3) To proffer policy recommendations in view of the BSL's effort to address exchange rate crisis in Sierra Leone.

In this study, it is our intention to utilise the Vector Autoregression Model (VECM), which equally like Autoregressive Distributed Lag (ARDL) approach, is proving popular in exploring studies connected with the J-Curve phenomenon, particularly in the West African sub-regions (Onafowora, 2003; Bangura et al., 2013; Schaling \& Kabundi, 2014; Onakoya \& Johnson, 2018; Englama et al., 2019). The researchers, through exploration of empirical literatures noticed that VECM has never been utilised to determine short and long-run relationship between exchange rate and trade balance (supposedly associated with the J-Curve phenomenon $)^{1}$ particularly for the Sierra Leone economy-hence, it is

\footnotetext{
${ }^{1}$ The uniqueness of this study is its approach to utilising three models that explore short and long-run association between exchange rate and trade balance, incorporating robust approach of the Marshall-Lerner condition, supposedly earmarked as Models 2 and 3 in the estimation procedure. Bangura et al. (2013) pursued effort was particularly focused in the utilisation of ARDL as the estimation technique, which is considered a novelty in setting the pace for on-going research in this area of study. It is believed that outcome from this study will complement the already published findings by the named authors, while taking into consideration the trajectory of macroeconomic dynamics in the country, given its methodology and scoping period of 202Q2-2019Q4.
} 
therefore hoped that the outcome of this study will add value (connected with recent developments) to policy recommendations earlier proffered by Bangura et al. (2013), which utilised ARDL with annual data and different timespan.

In view of the aforementioned introduction, the rest of the paper is detailed as follows: Section two addresses stylized facts about exchange rate and trade balance in Sierra Leone during the sample period, notably 2002Q2-2019Q4. Section three provides details of literature review, with emphasis on the effect of exchange rate on trade balance. Section four addresses details of the empirical models and data description, while section five provide a robustness approach to ascertain the Marshall-Lerner conditions, which asserts that the sum of the elasticity of both the exports and imports should be equal to one or greater than one. Finally, section six concludes the study with proffered policy recommendations for deliberation by leadership at the central bank and the Ministry of Finance.

\section{Stylize Facts: Exchange Rate and Trade Balance in Sierra Leone}

Figure 1 below provides stylized facts of Trade Balance and Exchange Rate dynamics in Sierra Leone during the observed period, 2002Q2-2019Q4. This provides movements that illustrate exchange rate depreciation and appreciation, as well as some level of trade surpluses (notably around 2012-2014) and persistent deficits in the country's trade balance over the years. Data were sought from the Bank of Sierra Leone (BSL) databank, with the Blue line indicating Trade Balance, while the Orange line indicating Real Effective Exchange Rate in their log form.

The plotted data in Figure 1 are in their logged format, with Real Effective Exchange rate represented as LREER and Trade balance represented as LTBAL over the scoping period. The LREER is reflective of fluctuations in the Leone (SLL) currency throughout most part of the early 2000 as the country was on a pathway of recovery from a decade of civil war. Due to increase appetite of economic agents to consume more of imported goods and services, institutions like the central bank has experienced a surge in import bills to settle foreign transactions. This on the whole is making it challenging for the BSL to meet the

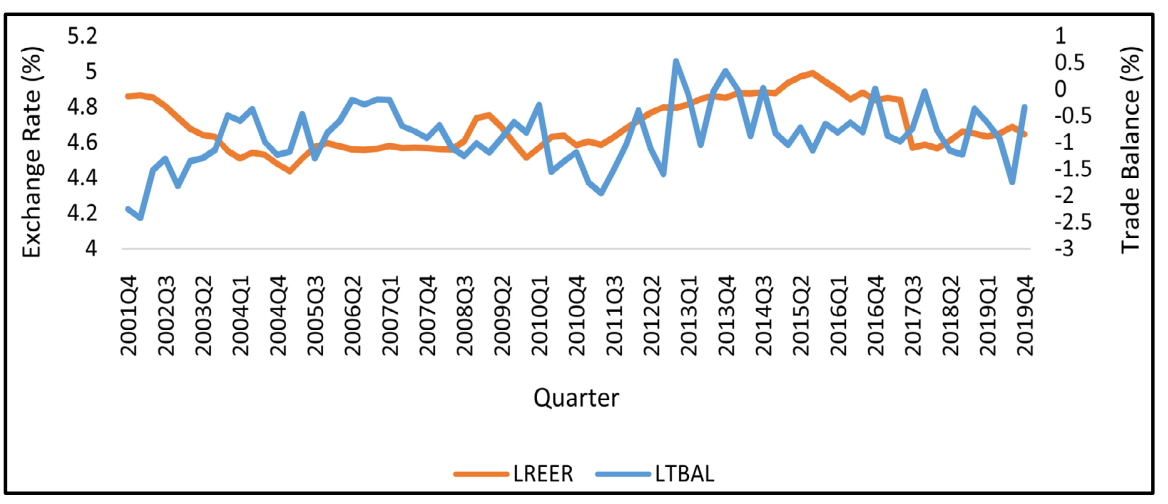

Figure 1. Trade balance and exchange rate (2002Q2-2019Q4). Source: Eviews output. 
statutory minimum three-months gross reserve requirement as stipulated by way of agreement with the International Monetary Funds (IMF), also an essential part of the primary criteria in the country's journey towards a single currency in the Economic Community of West African States, earmarked as the Eco currency (Egbuna, 2018).

The pattern and direction of exchange rate as shown is indicative of authorities' (Central Bank and Ministry of Finance) preference to operate on a freely flexible or floating regime as opposed to a fixed regime system (Sani et al., 2018; Pinto, 1988)-this type of exchange rate regime is market determined, also motivated by the action of demand and supply. With this, the country's currency is said to appreciate when the value of the domestic currency improves significantly against internationally quoted currencies. On the other hand, depreciation occurs when the domestic currency's value drops against international quoted currencies. Conversely, fixed exchange rate regime is administratively determined, which mostly contravene market forces of demand and supply (Sani et al., 2018; Pinto, 1988).

In this case, decision to adopt fixed exchange rate regime can be politically motivated, where the deciding rate is set by authority. In Sierra Leone, exchange rate management is the responsibility of the Ministry of Finance, while the monitoring is done by the BSL, (BSL Act, 2019). There are several factors that determine the type of exchange rate a country can adopt-specifically, Sierra Leone's link with international partners like the IMF and World Bank (in adherence to debt commitments) has made it highly possible for the country to adopt flexible exchange rate regime, which is in tandem with the free-market doctrine of capitalism (Chen, Dong, Tong, \& Zhang, 2018). Prior to the decision in 1986 to follow the pathway of floating exchange rate, the country was on a dual or pegged exchange rate regime, with the country's currency trading at an exchange rate of two Leones to a UK pound Sterling (Pinto, 1988: p. 27). A move in the direction of a flexible or floating exchange rate with very limited fiscal planning or reform in the exchange rate mechanism witnessed the beginning of inflationary pressure in the domestic economy (ibid). This also gave way to an unprecedented level of government subsidy in a bid to address gaps in the differential between the importation of high costly goods and services and worsening of trade deficit. The continued lack of adequate planning to manage the country's essential commodity exports meant that proceeds from exports were at a considerably low level, which also gave way to a continued depreciation of the Leone currency against international currencies like the US\$ (Jackson \& Jabbie, 2020a). This is reflected in Figure 1, which shows fluctuating patterns of the Real Effective Exchange Rate and Trade Balance throughout the scoping period.

As observed, Figure 1 also depicts noticeable surpluses in the country's Balance of Trade, except around 2002Q1, 2011Q2 and 2019Q3. A peak in trade balance during the period of 2012Q4 could be due to a surge in Iron Ore production, which was also backed by a corresponding increase in global market price for the precious mineral. During this period, Sierra Leone recorded its 
highest growth rate, with surpluses accrued to its current account balance, which also saw similar movement in the REER graph. The ill-managed state of boom time in Iron Ore production and its plummeted price around 2014 exposed the country's strength in weathering the twin-shock. This unearthed itself during the emergence of the Ebola crisis, and backed by an almost flatten-out commodity price of Iron Ore (Warburton \& Jackson, 2020; Jackson \& Jabbie, 2020a; Jackson \& Jabbie, 2019).

Another notable illustration in explaining the influence of exchange rate (REER) dynamics is provided below in Figure 2 with Broad Money. There is an attestable indication of an increase in Broad Money (M2) throughout the observed period, with exchange rate (REER) depicting signs of fluctuation. Such observable trend could be tied with customers' appetite to increase their consumption habit formation on imported (inelastic) goods and services owing to weaknesses in real sector operations to meet domestic consumption needs.

\section{Literature Review}

\subsection{Theoretical Overview}

The emphasis of this paper is based on the twin approach of Marshall-Lerner (ML) and J-Curve. The ML condition is modelled on the premise that in order for devaluation to be effective, the sum of the elasticity of import and export should be equal to or greater than one. On the contrary, critics have raised concerns about the effectiveness of the ML approach (which is said to satisfy both the necessary and sufficient conditions for an improvement in trade balance), where adherence to such condition do not necessarily improve trade balance (Bahmani-Oskooee \& Brooks, 1999; Bahmani-Oskooee, 1985).

Theoretically, ML condition is constructed on the premise that, where the sum of price elasticity for import demand and exports are equal to unity or greater than unity (coefficient values) in the long-run, the outcome (tantamount to currency depreciation) will eventually give rise to a surplus in the current account position (Kulkarni, 2007; Kulkarni \& Clarke, 2009; Onakoya \& Johnson, 2018).

This is illustrated as shown below in Equation (1):

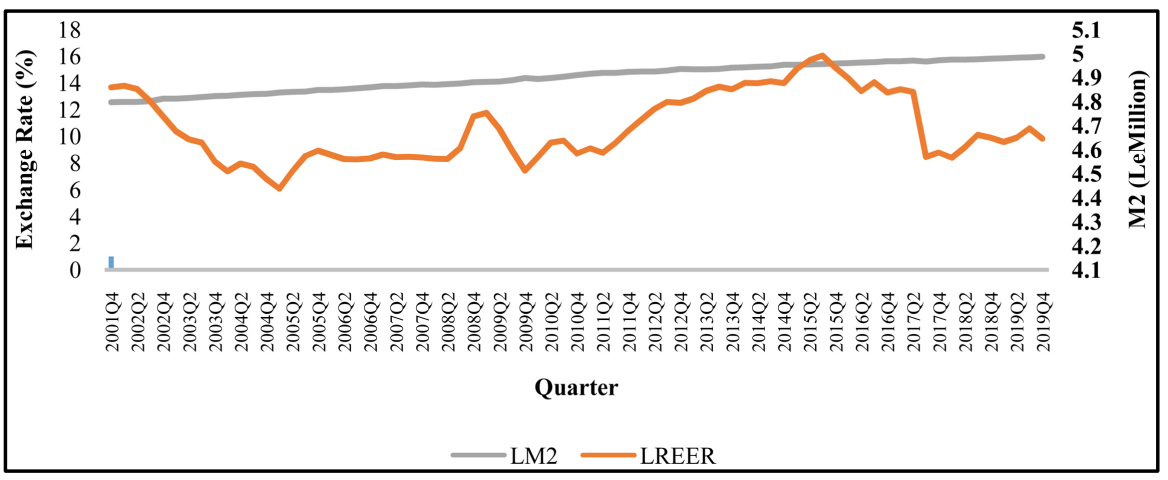

Figure 2. Relationship between REER and Broad Money (M2). Source: EVIEWS output. 


$$
P D_{i}+P D_{e} \geq 1
$$

where: $P D_{i}=$ Price elasticity of import

$P D_{e}=$ Price elasticity of export

Equally as addressed above, high level of inelasticity of exports and imports can also result in trade deficit or reduce trade surplus given the fact that expenditure on import bill will continue to rise due to high demand for essential goods and services. Figure 3 shows a visual illustration of the equilibrium condition of $\mathrm{ML}$ at Point $\mathrm{O}$, which reflect a situation where Eq.1 is equal to one $\left(P D_{i}+P D_{e}=\right.$ 1). The theoretical construct or explanation of J-Curve can also be extended to elucidate disequilibrium effect on a country's balance of payment adjustmentsuch approach incorporates Absorption, Monetary and Elasticity (see Adamu \& Itsede, 2010).

To digress further, the Absorption approach initially presented by Harberger (1950), was later worked on by Meade (1951), Alexander (1952); the conceptual idea behind this approach is that balance of trade is looked at from the angle of national income accounting. In this regard, improvement in balance of trade requires an increase in production relative to absorption or total expenditure (Adamu \& Itsede, 2010: p. 105; Bangura et al., 2013: p. 69). There is a contention in this approach, which indicate that devaluation of a currency will lead to inflationary pressure and ultimately result in price increase.

The Monetary approach emerged in the late 1950s and it is expressed in terms of a country's balance of payment and its supply of money (Adamu \& Itsede, 2010: p. 103; Bangura et al., 2013). It shows that a disequilibrium in the balance of payment will distort the money market or supply of money in circulation. High domestic demand for foreign currency could result in a run-down of a country's foreign reserves, which also have an impact in worsening the balance of payments position. Equally, outflow of foreign exchange reserves also have desirable impact in reducing money supply until a point is reached when it is equal to the money demand, hence restoring monetary equilibrium-this thereby makes it possible to halt the outflow of foreign exchange reserves. The opposite is also true where excess demand for money induces foreign

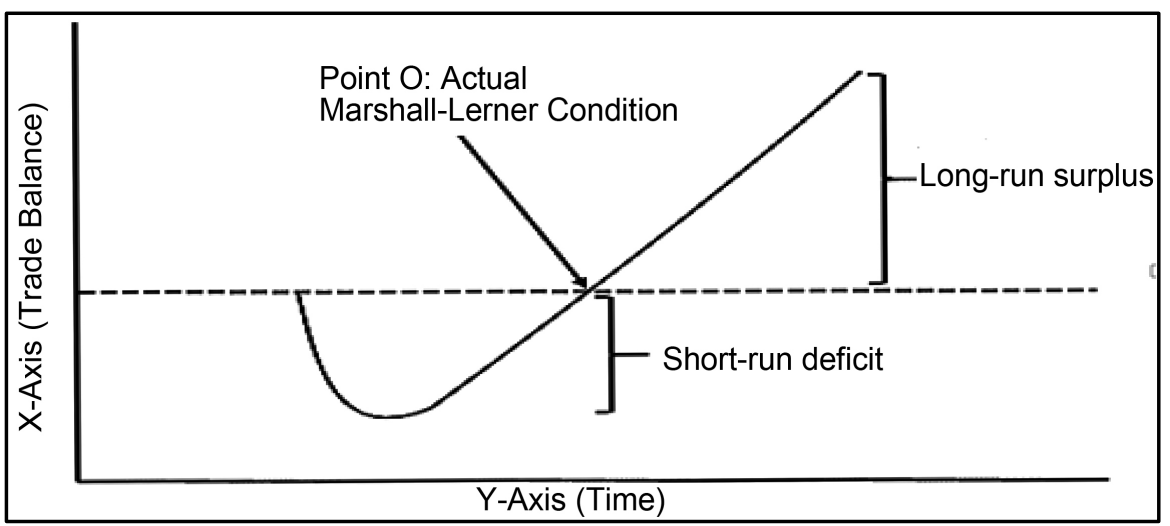

Figure 3. Illustration of J-Curve effect. Source: Hand-drawn and illustrated by authors. 
exchange reserves inflow, with an ultimate impact on balance of payment surplus.

The Marshall-Lerner condition asserts that the sum of the elasticity of demand for import and exports must be equal to one or greater than unity for devaluation to improve the balance of payment position. There is also a need to throw light on the Elasticity approach (Du Plessis et al., 1998); according to Robinson (1947), the elasticity approach emphasises the effect of exchange rate on exports and imports of a country, and also trade account balance by ignoring all other variables, particularly income (Adamu \& Itsede, 2010).

The incorporation of all three approaches into the study as expressed in Equations (5), (6) and (7) have made it possible for the authors to verify their relevance in the context of Sierra Leone. Based on theory, balance of trade position can be affected by changes in associated variables connected with domestic and foreign income, money supply stock and exchange rate, also accounted for in the model equations to determine the J-Curve effect and the Marshall-Lerner condition.

\subsection{Empirical Review}

This section highlights the empirical literature with focus on the J-Curve and ML condition. In view of structural problems experienced in the Sierra Leone economy, major part of the empirical literatures have been devoted to developing economies around the world, and notably those with similar macroeconomic features as indicated below.

Ogundipe, Ojeaga, Oluwatomsin and Ogundipe (2013) empirically investigated the impact of currency devaluation on Nigeria's trade balance. Data utilised spanned from 1970 to 2010, with Johansen co-integration utilised as the main methodological tool, and backed by Variance Decomposition to assess the overall impact for policy implementation. Their findings show long-run relationship existing between the dependent variable, which is trade balance and the exogenous variables (namely domestic income, domestic and foreign money supply, domestic interest rate and nominal exchange rate). They concluded that the level of money supply has a major impact on the trade balance adjustment and that devaluation of the exchange rate worsens the trade balance of Nigeria in the long run.

Bangura, Denison-George and Caulker (2013) pursued a similar study using an ARDL (incorporating Bounce Testing, Cointegration to determine speed of adjustment in error correction terms) to addressing the role of exchange rate in determining the short and long-run behaviour of Sierra Leone's trade balance, with annual data spanning 1980 to 2011. The study revealed a stable long-run relationship running between trade balance, real exchange rate, domestic income, foreign income and money supply variables-it was also proved that domestic income and money supply were the strongest influence of trade balance in the long-run model estimation. The Marshall-Lerner condition was proved 
not to hold in the long-run, while the use of error correction to determine short-run effect of the trade balance proved to be significant, with the appropriate (-ve) sign to attest the existence of J-Curve effect in the short-run. Given the existence of structural bottlenecks, the authors concluded for authorities to encourage diversification of commodity exports, with favourable efforts to boost domestic production in a bid make it competitively worthy to support domestic consumption of similar imported items.

Baba and Yazici (2016) also carried out a study of the J-curve phenomenon between Nigeria and fifteen European countries using the ARDL approach. The outcome of their study revealed contrasting picture. Utilisation of aggregated data for the fifteen countries shows that the J-curve phenomenon does not hold for Nigeria, but a disaggregated outcome of the data during the same time period, with focus on bilateral trade or each of the 15 European countries, revealed that only four countries (Germany, Italy, Denmark and Austria) revealed evidence of the J-curve phenomenon with Nigeria.

Bahmani-Oskooee and Durnaz (2016) investigated the effect of exchange rate changes on the trade balance in Turkey. In this study, they made use of asymmetric cointegration and error-correction modelling; the use of non-linear adjustment on the exchange rate data was explored on the trade balance of 57 industries that are in trade arrangement with Turkey and EU. The findings revealed short-run asymmetry effect in 24 industries, with the remaining 23 countries showing long-run asymmetry effect. In conclusion, the study shows that both large and small industries are subject of asymmetry effects.

Iyke and Ho (2017) examine the response of Ghana's trade balance to shocks in exchange rate. Quarterly data ranging from 1986 to 2016 were used in this study. Furthermore, the ARDL approach to cointegration was utilized, but the study could not establish the expected short and long run relationship between Ghana's currency depreciation and its own country trade balance. However, when the non-linear ARDL approach was used, they confirm that the J-Curve phenomenon holds in Ghana. The results of this non-linear approach shows that a real depreciation improves Ghana's trade balance, while real appreciation seem not to show any impact throughout the data span period of the study.

George and Choi (2019) utilised two dynamic model approaches to address how changes in trade barriers contribute to the dynamics of the US trade balance and real exchange rate. The data used in this study spanned from 1980 to 2015 . The model decomposed fluctuations into trade balance and business cycle asymmetries, with the final empirical outcome showing three different findings. The first findings revealed result of a relatively large US trade deficits as a share of GDP in the 2000s compared to the 1980s, which reflect a rise in the trade share of GDP. The second findings show that controlling for trade, roughly about sixty percent of net trade flows are due to business cycle asymmetries. Finally, the third findings revealed two-thirds of the contribution of business cycle asymmetries be the result of lagged responses. 
Bahmani-Oskooee, Usman and Ullah (2019) also explored the trade balance of 41 industries, which are in trade relationship with Pakistan and the United States of America, considered to be one of Pakistan's largest trading partners according to trade direction data. A linear ARDL model was use as the empirical tool to conduct the research, with the result showing J-Curve exist for only ten industries. They also pursued a non-linear ARDL model estimation, which supports asymmetric outcome of J-curve effect for 19 industries. Eight industries experienced depreciation in the Rupee, while eleven industries experienced an unfavourable appreciation of the Rupee.

Hunter (2019) revisited an earlier work done by Bahmani-Oskooe and Fariditavana in 2016. The Nonlinear Autoregressive Distributed Lag (ARDL) model was used to examine the J-curve phenomenon for the Chinese economy. With four different linear ARDL models utilised as well, the outcome revealed that only two of the models supported the J-curve phenomenon in China. A repeat of the four linear ARDL models were utilized; three of them were in support of the J-curve phenomenon.

In view of the aforementioned empirical reviews in pursuit of exploring whether the J-Curve hold for Sierra Leone, this study in particular seeks to utilise the VECM approach. Despite similar work has been pursued in more recent times, the choice of methodology is hereby perceived as a novelty in adding value to the research gap by examining the twin effect of J-Curve and Marshall-Lerner condition in Sierra Leone using quarterly time series data spanning 2002Q2-2019Q4. In view of earlier studies in this area (reference to Englama et al., 2019; Bangura et al., 2013; Adeniyi et al., 2011), the researchers wish to extend the frontier by utilising three models. The models take cognisance of the twin approach of J-Curve and the Marshall Lerner condition where Model 1 is the Trade Balance, while Models 2 and 3 are the disaggregated Import and Export components to ascertain the Marshall-Lerner condition as part of the robustness of the study. This then makes it possible for the ML condition to explore the theoretical proposition of both the Monetary and Elasticity approach, which is independent of the theoretically construct of absorption and monetary approach in the determination of the J-Curve phenomenon.

\section{Model, Data Description and Empirical Analysis}

\subsection{Methodology}

\subsubsection{Estimation Procedure}

Alfred Marshall believes that consumers buy goods and services based on their personal satisfaction. In view of this notion, the dynamic specification approach was developed, which is rooted on the imperfect substitute model of Goldstein and Khan (1985). The reduced form of the trade balance is expressed as shown in Equation (2) below (also excerpted in Akbostanci, 2004):

$$
T B A L=f\left[\gamma, \gamma^{*}, \rho\right]
$$

where 


$$
\rho=\left(P^{*} \mid P\right) E
$$

where TBAL is the Trade Balance, which is a function of $\gamma$ as the domestic income, $\gamma^{*}$ is the foreign income and $\rho$ is the Real Effective Exchange Rate (REER). In the second expression $\left(\rho=\left(P^{*} \mid P\right) E\right), P^{*}$ and $P$ are the foreign and domestic prices, while $E$ is the Nominal Exchange Rate. The partial derivative of $\partial T B A L / \partial$ as shown in Equation (2) above should be negative in the short run and positive in the long run (Akbostanci, 2004: p. 60).

Variety of methodologies that have been applied in a bid to test the existence of J-Curve effect. Specific to this study, the researchers have restricted their investigation to the use of Vector Error Correction Model (VECM) through expansion of a system of equations (following from Equation (2)) as provided below in a matrix of equations:

$$
\begin{gathered}
\Delta X_{t}=\sum_{i=1}^{k-1} \tau \Delta X_{t-1}+\pi X_{t-k}+\mu+\varepsilon_{t} \\
\pi=\alpha \beta^{\prime}
\end{gathered}
$$

where: $X_{t}$ is a vector of stochastic variables in the form " $p \times 1$ ”.

For this study, $X_{t}$ which equals $\left[T B A L, Y, Y^{*}, \rho\right]$ should integrated to the order I(1).

$\mu=$ intercept term,

$\varepsilon_{t}=$ error term, which is considered to be white noise.

Given the fact that $X_{t}$ is $\mathrm{I}(1)$, linearize combination of indicator(s) stationary order are invariably taken to be cointegrated. With the presence of cointegration, it is presumed to be in Error Correction form as represented in Equation (3) (Engle and Granger, 1987).

As mentioned earlier, $\pi$ in Equation (4) is a matrix form expression, with $\alpha$ taken to be a vector of adjustment coefficients. While $\beta$ is a vector of cointegrating relations, while both $[p \times r]$ are assumed to be in matrix form (Akbostanci, 2004: p. 61). Due to the existence of error correction form on the cointegrating relations, the empirical investigation can commence by estimating for long-run cointegrating relationship between the variables, and then followed by estimating Equation (3) to detect for short-run dynamics in the model.

Our justification for utilizing VECM is based on the fact that all variables are of $\mathrm{I}(1)$ order as revealed from unit root test outcomes-equally, it also provide a quicker means of determining speed of adjustment once the cointegration has been determined through the Johansen Cointegration test. In pursuance of our justification for the use of VECM, we have attempted to utilise three econometric model equations in a bid to achieve the research objectives as expressed below:

$$
\begin{aligned}
& \text { LTBAL }_{t}=\propto_{0}+\propto_{1} \text { IREER }_{t}+\propto_{2} \text { lM }_{t}+\propto_{3} l F y_{t}+e_{t} \\
& \text { LImport }_{t}=\propto_{0}+\propto_{1} \text { IREER }_{t}+\propto_{2} l M 2_{t}+\propto_{3} l D y_{t}+e_{t} \\
& \text { LExport }_{t}=\propto_{0}+\propto_{1} \text { IREER }_{t}+\propto_{2} l M 2_{t}+\propto_{3} l F y_{t}+e_{t}
\end{aligned}
$$

Equation (5) is modelled on the premise of satisfying the theoretical assump- 
tion of both the "Absorption and Monetary" approaches (already exemplified in Equations (2) to (4) above), while Equations (6) and (7) simply justify the elasticity approach (with monetary component), which states that the sum of the elasticity of Import and Export should be equal to or greater than one.

\subsubsection{Data Utilization and Description}

In order to empirically determine the twin effect of the J-Curve effect and Marshall-Lerner condition in Sierra Leone, the researchers have produced variables in their logarithmic form, sourced from the Bank of Sierra Leone dataware house and Balance of Payment Section in the Research Department - these include the following: Trade Balance (TB), Real Effective Exchange Rate (REER), Broad Money (M2) and Foreign Income (Fy)", with data ranging from 2002Q2-2019Q4 as exemplified in Figures 4-10 below. In the Trade Balance equation, we also utilised variables such as "Import, Export and Domestic Income (LDY)" as a way of ascertaining the Marshall-Lerner condition. A summary statistics of all variables are indicated in Appendix 7, which shows that 72 observations were utilised for all variables selected. The data range shows a moderately skewed distribution (ranging between -0.09 to 0.42 ), while the Kurtosis values are in the range of less than two, indicating that the dataset possess lighter tails in a normal distribution as referenced in Appendix 7. The Jarque-Bera results from the dataset shows the goodness of fit test of Skewness and kurtosis, and in this case as indicated

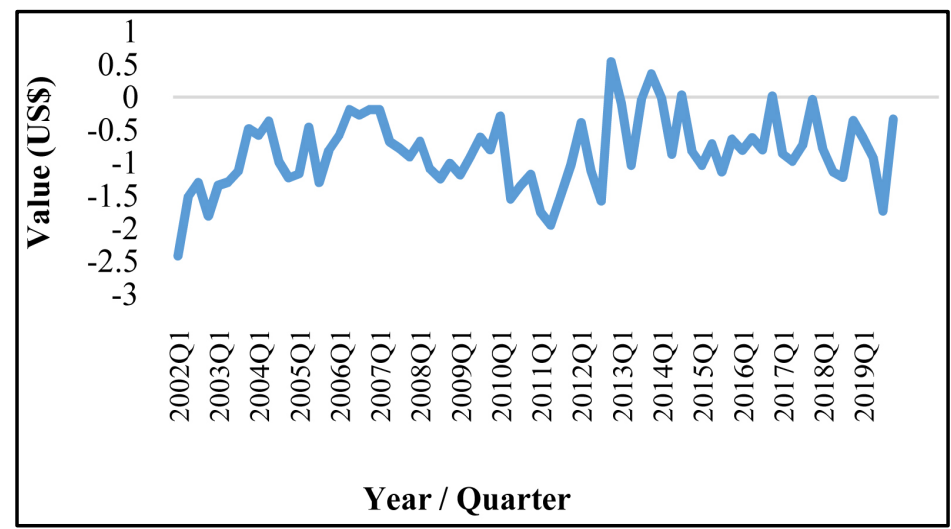

Figure 4. Trade Balance (Log).

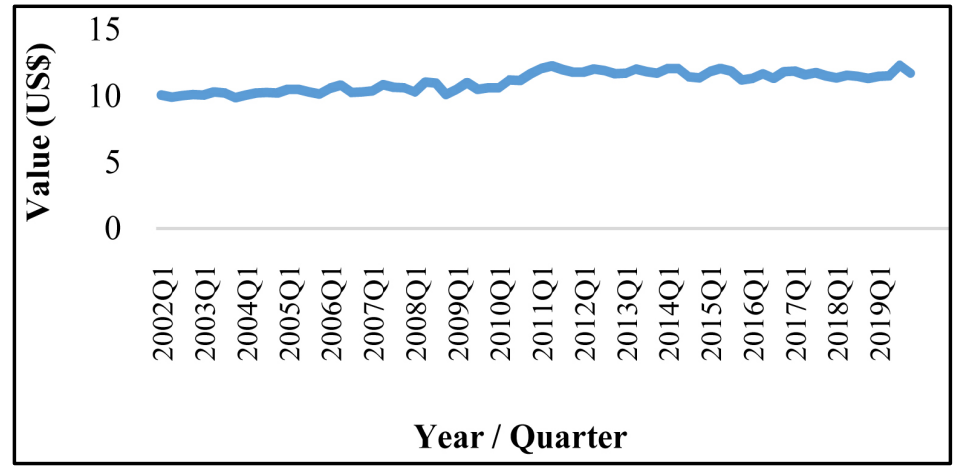

Figure 5. Import (Log). Source: EVIEWS output. 


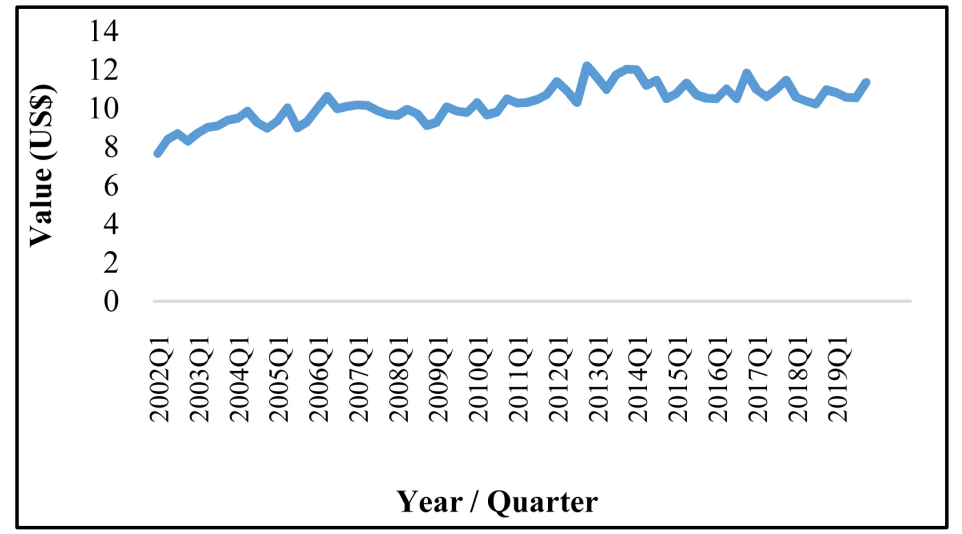

Figure 6. Export (Log). Source: EVIEWS output.

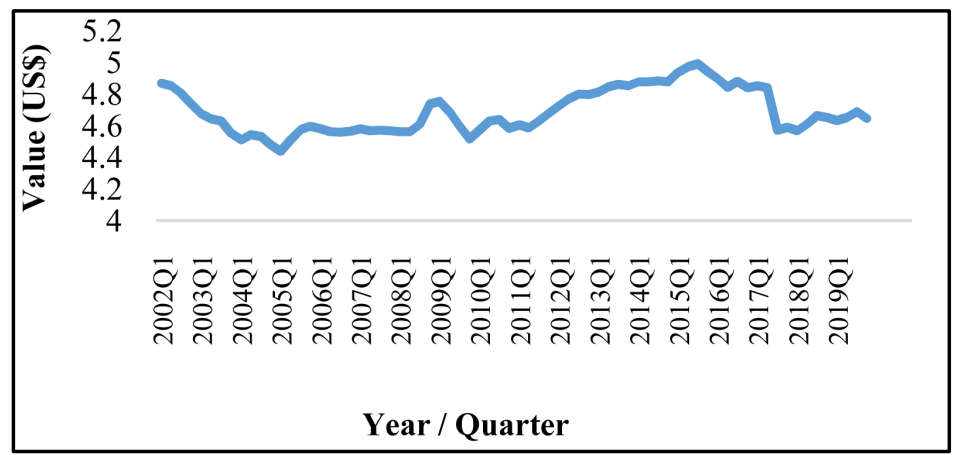

Figure 7. Real effective exchange rate (Log). Source: EVIEWS output.

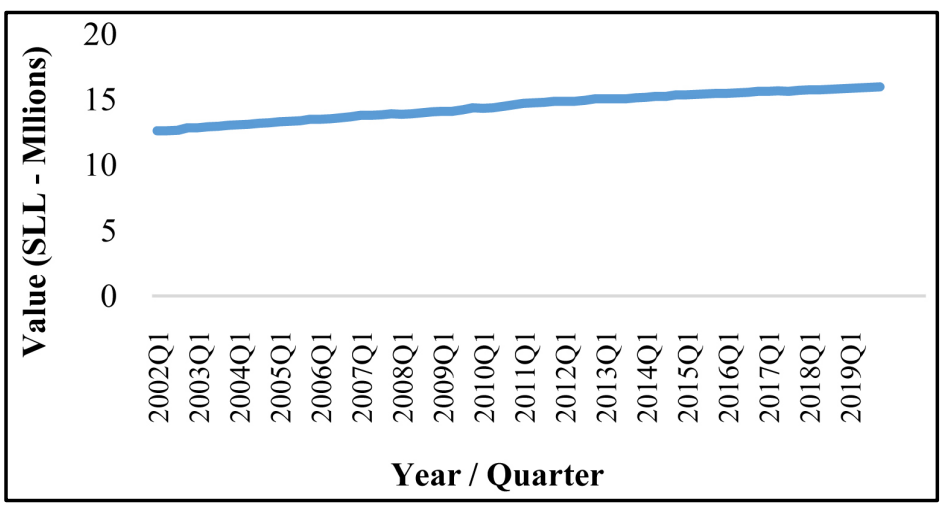

Figure 8. Broad Money (Log). Source: EVIEWS output.

in Appendix 7, the results are not normally distributed. Detailed description of the variables is illustrated below (see Figures 4-10 for illustration of the variables).

Trade Balance (TBAL): Figure 4 is construed as the difference between the monetary value of a country's exports and imports over a defined period, normally expressed in one calendar year. The term is used to signify goods and services traded by Sierra Leone and her major trading partners, notably in this case the USA. With reference to Figure 4, where the exports of a country is greater than its imports, then a "surplus or positive terms of trade" will be experienced. 


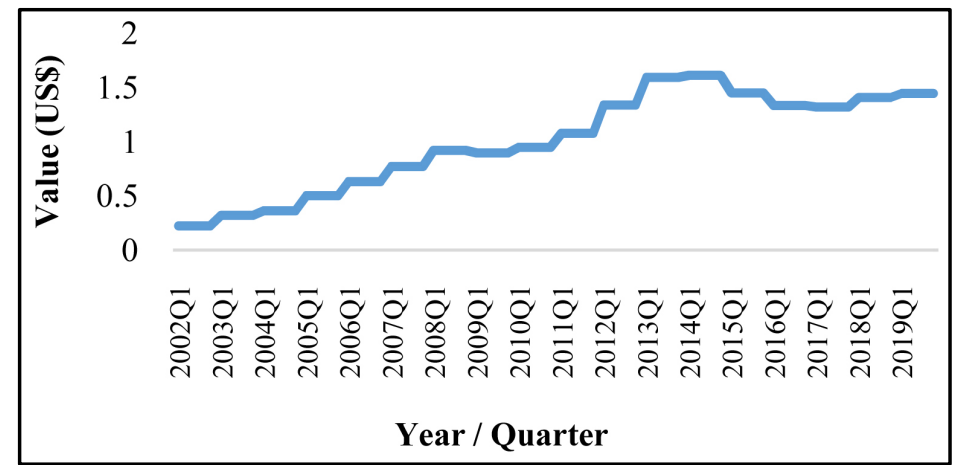

Figure 9. Domestic income (Log). Source: EVIEWS output.

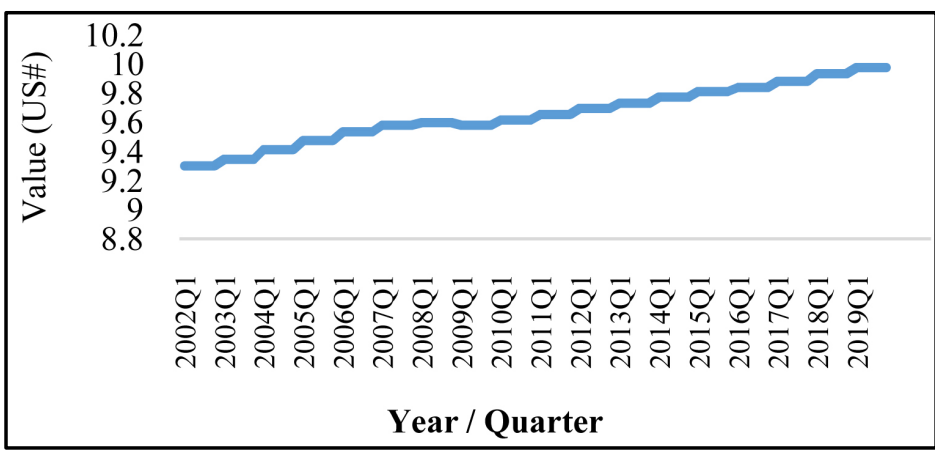

Figure 10. Foreign income (Log). Source: EVIEWS output.

Conversely, if imports are greater than exports, then a "deficit or negative terms of trade" is said to occur. The notion of a trade deficit anecdotally ascribed as bad for a country can be opened to contentious criticism by economists (IGM Forum, 2014).

Import (Imp.): Figure 5 depicts the Import variable in log form. Import is defined as goods bought or that transported in one country that were originally produced in another. In the case with Sierra Leone, there has been a persistently high import of goods and services movement in the country on account of the low productive base of the real sector, which also induce pressure on the country's ability to gain control of its exchange rate mechanism.

Export (Exp.): Figure 6 depicts Export variable in log form. Export is defined as goods and services that are produced in one country and sold to buyers in another country. In the study of modern economic performance, it is always an expectation for export to be higher than import so as to enable a country's terms of trade to be positive. This also offer firms the opportunity to produce more in a situation where both domestic and external consumption are high, thereby giving rise to the opportunity for higher scope of employment for nationals and market efficiency.

Real Effective Exchange Rate (REER): Figure 7 depicts the Real Effective Exchange Rate (REER) in log form. This is the weighted average of a country's currency in relation to an index or basket of other major currencies. In this case, the weights can be determined through comparison of relative balance of a 
country's currency against other currencies within the calculated index. In this regard, the higher the trade relation of a country with other trading partners, the higher the weight attached to the index.

Broad Money (M2): Figure 8 depicts Broad Money in log form. This is a measure of the amount of money in the national economy, which is inclusive of liquid or narrow money (bank notes, coins, check accounts for overnight payments, etc.) and other non-liquid forms of money, for example savings and other forms of deposit. The use of the work Broad Money can be construed differently across regions or countries. In the context of Sierra Leone, the definition of Broad Money is exclusive of financial market deposit such as Treasury Bills.

Domestic Income (Dy): Figure 9 depicts Domestic Income in log form. This is income earned within a national economy, for example, earnings from gross national income accounting or commonly referred to as the gross domestic income. Such income will be inclusive of the total of all forms of income generated through productive activities such as goods and services nationwide - example of such computation include taxes, income earned through employment, profits from business operations and less subsidies.

Foreign Income (Fy): Figure 10 depicts Foreign Income in log form. This is construed in the same way as that of the domestic or gross national income accounting computation. The difference lies on the fact that such income is generated by a country's trading partners. For this study, we have restricted the foreign income data to the United States of America (USA) - this is based on the fact that the USA account for over $30 \%$ of the world's trade. In addition, Sierra Leone's accounting system of trade is highly dominated in the US\$ currency.

Our justification for utilising the identified variables is based on their relative importance to the long-term stability of the Sierra Leone economy, particularly in assessing theoretical approaches connected with Absorption, Monetary and Elasticity concepts of both the J-Curve phenomenon and the Marshall-Lerner condition.

\subsection{Empirical Analysis and Discussion of Results of Results}

This section presents the empirical analysis and discussion of results using VECM to examine the long and short-run outcomes of the Trade Balance Model. This process commences with initial test of Unit Root for the identified variables, with preference given to the Phillips Peron (PP) test on the basis of a large sample sized data (above 40) as demonstrated in Appendix 1. All Unit Root tests manifest I(1) order, which motivated the need to explore the VAR approach to determine lag length criteria as shown in Appendix 2. Basic diagnostic tests relating to the models' stability were then determined prior to the Johansen Cointegration Test outcome (to determine long and short-run cointegration coefficients) and followed by the VECM estimation. The basic expression for the TBAL model is shown below in Equation (5).

Following on from determining the lag selection, which according to the AIC 
indicate lag 5, we then checked for co-integration as shown in Appendix 3. The evidence shows at least one cointegrating equation, which prompted the use of VECM as the preferred methodology to determine short-run and long-run association in the models (see Appendix $\mathbf{4}$ for details).

Table 1 provides evidence of the estimated short and long run estimation for Model 1 under the VECM framework. Confirming cointegration informed the estimation of the long run model to determine the long run impacts of the various independent variables on the dependent variable (TBAL). The output shows that most of the coefficients are significant (consistent with their a-priori expectations) at the threshold level of significance at the 5\% level, except for the coefficient of the REER. In the case of the short run model, the error correction term (ECT), supposedly provide estimate of the speed of adjustment at which the dependent variable returns to equilibrium after changes in other variables-the outcome for this is negative and significant. The ECT indicated a feedback of approximately 73 percent of the previous year's disequilibrium from the long run. The model was proven to have a satisfactory explanatory power as reflected in the R-Square value, which depicts that approximately 40 percent of the variation in the dependent variable can be explained by the independent variables. Moreover, the F-statistics confirm that the independent variables are jointly significant in explaining the dependent variable. Despite the apriori expected (negative) sign associated with REER, it is still insignificant and hence, could be interpreted as weakly exogenous in explaining a stable long-run relationship with Trade Balance, hence a fragile J-Curve as depicted in the Impulse response outcome (Table 1). This result is also consistent with the empirical evidences suggested Greenwood (1984) and Wilson and Tat (2001), to name a few.

To address the Short-run outcome, we then imposed a restriction on the TBAL model (with particular attention to the REER variable), through the use of the "Wald Test". The short run outcome of the WALD test (Table 2) at 0.089 shows no causality running from REER to TBAL.

Table 1. Long and short run dynamics for model 1 (Trade Balance).

\begin{tabular}{|c|c|c|c|c|c|}
\hline \multicolumn{6}{|c|}{ Long-run Estimated Model: } \\
\hline $\mathrm{LTBAL}=1.000 \mathrm{LTBL}_{-1}$ & -1.1155 LREER $_{-1}$ & $+1.57332 \mathrm{LM} 2_{-1}$ & $-6.4205 \mathrm{LFY}_{-1}$ & +45.3561 & \\
\hline & $(0.65059)$ & $(0.57332)$ & $(2.50730)$ & $(8.54371)$ & \\
\hline & {$[-1.71458]$} & [2.73819] & {$[-2.56071]$} & {$[5.30871]$} & \\
\hline \multicolumn{6}{|c|}{ Short-run Estimated Error Correction Model: } \\
\hline DLTBAL $=-0.73 \mathrm{ECT}_{-1}$ & +0.006 DLTBAL $_{-1}$ & -2.38 DLREER $_{-}$ & $+1.46 \mathrm{DLM}_{-1}$ & $-3.63 \mathrm{DFY}_{-1}$ & -0.85 \\
\hline$(0.1425)$ & $(0.1257)$ & $(1.1497)$ & $(1.4407)$ & $(3.1118)$ & $(0.2754)$ \\
\hline$[-5.1568]$ & {$[-0.0442]$} & {$[-2.0732]$} & [1.0114] & {$[-1.1665]$} & {$[-3.0779]$} \\
\hline
\end{tabular}

Source: EVIEWS output. Note: ( ) represent standard error values, while [ ] represent T-Statistic values.

${ }^{2}$ Dolado. J.J., and Lutkepohl, H. (1996). Making Wald Tests Work for Cointegrated VAR Systems. Econometric Reviews, Vol. 15(4): pp. 369-386. 
Table 2. Wald test.

\begin{tabular}{cccc}
\hline Test Statistic & Value & Df & Probability \\
\hline F-statistic & 2.517291 & $(2,63)$ & 0.0888 \\
Chi-square & 5.034581 & 2 & 0.0807
\end{tabular}

Source: EVIEWS output.

\section{Post-Estimation Test Outcomes}

In order to ascertain the efficiency of the model, we also proceeded by running other relevant diagnostic tests as shown below:

Table 3 indicates that there is no serial correlation at the second lag.

Table 4 outcome shows no evidence of Heteroskedasticity.

\subsection{Impulse Response}

Figure 11 depicts evidence of impulse response function following an aggressive five period shock to the Trade Balance Model-the outcome shows a high response of shock from TBAL to LREER initially, but decrease on account of the short-run effect of the country's depreciation of its currency to accommodate higher appetite of its export commodities to the outside world from period two onward to period four. There is a pick-up, which also depict a classic case of the J-Curve effect, but with some level of moderating effect during the remaining shock period, notably periods 4 and 5 . The effect of LREER on itself seem to be persistent for almost half of the shock period, but thereafter declined on account of a weak real sector operation, which has given scope for higher level of import demand. Equally, the effect of LM2 response on LREER was high initially, but diminished during the latter period of the shock. Also, the shock impact of LREER to LFY was initially strong, but low earnings from exports and coupled with weaknesses in real sector activities is also making it very difficult for the situation to be sustained.

Table 5 shows estimate of Variance Decomposition (VD) for LREER on TBAL and other indicators of interest. The VD outcome for LREER was very much driven by its past value(s), thereby reinforcing the outcome as seen from the impulse response function technically linked with the subject of adaptive expectations, which drives the inertia of persistent depreciation of the Leone currency. This indicates that past depreciation of exchange rate is a good predictor of its current and future trends. Trade balance also appeared to be a strong predictor as the estimate reflects on average, 3 percent of the variance in exchange rate problems implying an easy pass-through effect of exchange rate changes on prices of imported goods and services consumed in Sierra Leone, which also have a lag effect. In the short-run, changes in Broad Money and Foreign income also proved to be insignificant in driving variations in exchange rate crisis in Sierra Leone, which also justify results from the impulse response functions.

\section{Model Robustness: The Marshall-Lerner Condition}

To robustly check for the certainty of J-Curve effect in Sierra Leone, we also 
Table 3. Serial correlation.

\begin{tabular}{ccc}
\hline Lags & LM-Stat & Prob. \\
\hline 1 & 44.43028 & 0.0002 \\
2 & 22.74009 & 0.1209 \\
& Probs from chi-square with 16 df. & \\
\hline
\end{tabular}

Source: EVIEWS output.

Table 4. Heteroskedasticity test.

\begin{tabular}{cccc}
\hline Chi-sq & Df & Prob. \\
\hline 137.4366 & 140 & 0.5455 \\
\hline
\end{tabular}

Source: EVIEWS output.

Table 5. Variance decomposition.

\begin{tabular}{cccccc}
\hline Period & S.E. & LTBAL & LREER & LM2 & LFY \\
\hline 1 & 0.478243 & 1.834614 & 98.16539 & 0.000000 & 0.000000 \\
2 & 0.503275 & 2.500211 & 96.24295 & 0.884272 & 0.372571 \\
3 & 0.508897 & 2.587640 & 96.39726 & 0.711277 & 0.303828 \\
4 & 0.517005 & 2.891163 & 95.99858 & 0.683589 & 0.426670 \\
5 & 0.524027 & 3.277362 & 95.19835 & 0.704472 & 0.819819 \\
& & Cholesky Ordering: LTBAL LREER LM2 LFY & & \\
\hline
\end{tabular}

Source: EVIEWS output.

\section{Response to Cholesky One S.D. Innovations}
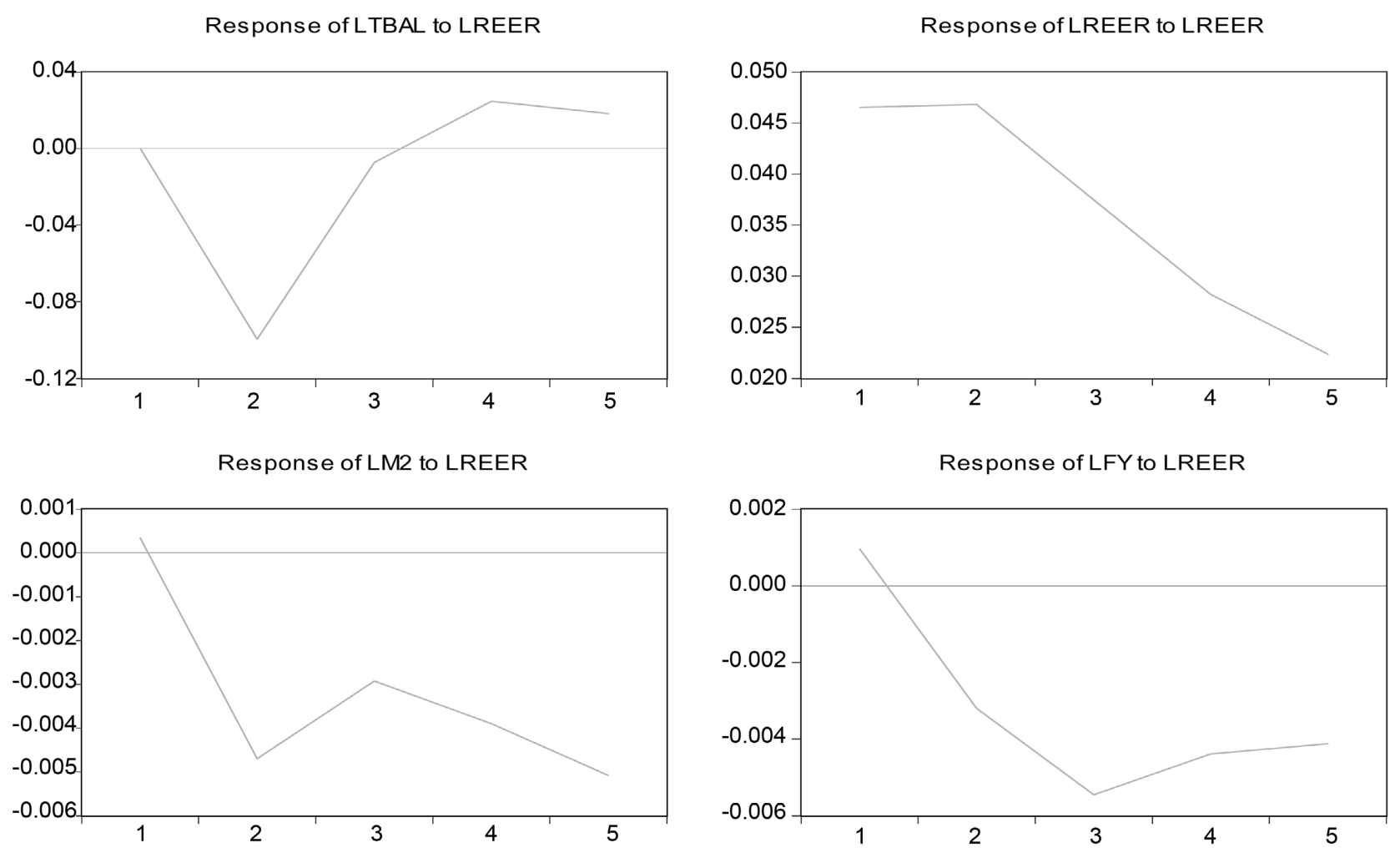

Figure 11. Impulse response. Source: EVIEWS output. 
went further by utilising two separate model equations. Linked with Equations (6) and (7), this is to ascertain the Marshall-Lerner condition (where price elasticity of Import and Export is at least equated to 1). The outcome of short and long-run association of the models (Import and Export) are specified in Sections 5.1 and 5.2-this also provide an indication as to whether Equation (1) is sufficiently satisfied.

\subsection{Import Model}

Short-run equations below (see Appendix 5 for details of the VECM estimation output).

In the Import Model (Table 6) provided, the coefficients of both the real effective exchange rate (LREER) and money supply (LM2) are negative and appear to be significant at the five percent level, implying that in the long run, a percentage increase in REER and money supply will lead to a decline in imports. The coefficient of domestic income (LDY) was however shown to be insignificant.

Results from the short run model indicate that the ECT is significant and negative, with a feedback of 34 percent of the previous year's disequilibrium from the long run. The coefficient of most of the variables is insignificant, except for domestic income (DLDY) indicating that a change in domestic income in the short-run has the tendency of increasing imports. To address the situation in the Short-run, we also subjected the restricted model (with particular attention to the REER variable) to the Wald Test. After imposing restrictions on the coefficient target variable(s) with the WALD Test, the outcome of 0.55 indicate no short-run causality running from REER to LImport.

\section{Relevant Diagnostic Tests}

The evidence in Table 7 and Table 8 respectively shows no evidence of Serial Correlation and Heteroskedasticity.

\subsection{Export Model}

The long run adjustment of this model is expressed thus (see Appendix 6 for

Table 6. Long and short run dynamics for model 2 (import).

\begin{tabular}{|c|c|c|c|c|c|}
\hline \multicolumn{6}{|c|}{ Long-run Estimated Model: } \\
\hline $\mathrm{LIMP}=1.000 \mathrm{LIMPORT}_{-1}$ & -1.7879 LREER $_{-1}$ & $+0.0475 \mathrm{LDY}_{-1}$ & $-0.6353 \mathrm{LM}_{-1}$ & +6.4357 & \\
\hline & {$[-3.29331]$} & {$[0.094791]$} & {$[-3.09749]$} & {$[2.15650]$} & \\
\hline \multicolumn{6}{|c|}{ Short-run Estimated Error Correction Model: } \\
\hline DLIMP $=-0.34 \mathrm{ECT}_{-1}$ & +0.02 DLIMP $_{-1}$ & +0.24 DLREER_1 & $+1.64 \mathrm{DLDY}_{-1}$ & $+0.91 \mathrm{DLM} 2_{-1}$ & -0.05 \\
\hline$(0.1013)$ & $(0.1305)$ & $(0.6868)$ & $(0.5866)$ & $(0.8551)$ & $(0.0570)$ \\
\hline$[-3.3768]$ & {$[0.1747]$} & {$[0.3484]$} & {$[2.7877]$} & {$[1.0604]$} & {$[-0.9058]$} \\
\hline
\end{tabular}

Source: EVIEWS output. Note: ( ) represent standard error values, while [ ] represent T-Statistic values. 
Table 7. Serial correlation (robustness).

\begin{tabular}{ccc}
\hline Lags & LM-Stat & Prob \\
\hline 1 & 30.08991 & 0.0775 \\
2 & 20.67019 & 0.1915 \\
\hline
\end{tabular}

Source: EVIEWS output.

Table 8. Heteroskedasticity (robustness).

\begin{tabular}{ccc}
\hline Chi-sq & Df & Prob. \\
\hline 103.5233 & 120 & 0.8584 \\
\hline
\end{tabular}

Source: EVIEWS output.

details of the VECM estimation output).

Result as shown in Table 9 for the Long run Export Model reflects that both the coefficients of REER and foreign income are negative and significant. This indicates that in the long run, ceteris paribus, a percentage depreciation in the REER and an increase in foreign income (LFY) will lead to a decline in export in Sierra Leone. The Error Correction Term (ECT) possess the appropriate sign and was significant with a feedback of approximately 36 percent of the previous year's disequilibrium from the long run. The coefficient of all the other variables is insignificant. To address the situation in the Short-run, we also subjected the restricted model (with particular attention to the REER variable) to the Wald Test. After imposing restrictions on the coefficient target variable(s) with the WALD Test, the outcome greater than 5\% (0.36) indicated no short-run causality running from REER to LExport.

The outcome in Table 10 shows no evidence of serial correlation for the first lag period, but manifesting itself in the second period. Equally, the joint outcome of the Jarque-Bera (Skewness and Kurtosis) test shows no evidence of normality, which could be explained on account of the large data sample in use and policy shift.

The outcome in Table 11 shows no evidence of Heteroskedasticity, which is above 5\%, hence this indicate that the Export Model for checking robustness of the J-Curve effect is fit-for-purpose.

\section{Conclusion and Policy Recommendations}

This study empirically examined whether the J-Curve phenomena hold in Sierra Leone using quarterly data from 2002Q2 to 2019Q4. The study employed three separate VECM Models. Model 1 as the base model, provides evidence of the overall trade balance. Outcome from this model shows that the J-Curve effect holds for Sierra Leone in the long-run, but is weakly determined given the insignificant level ascribed to REER despite its negative sign, which proved to be consistent with apriori expectation. The result is also attested in the impulse response function diagram as shown in Figure 11 (implied by the innovation 
Table 9. Long and short run dynamics for model 2 (export).

\begin{tabular}{ccccc}
\hline \multicolumn{5}{c}{ Long-run Estimated Model: } \\
\hline LEXPORT $=1.000$ LIMPORT $_{-1}$ & 1.000 LEXPORT $_{-1}$ & -2.9119 LREER $_{-1}$ & -2.473 LFY $_{-1}$ & +27.2946 \\
\hline & & $(093381)$ & $(0.69204)$ & $(0.67481)$ \\
& & {$[-3.11828]$} & {$[-3.57372]$} & -0.05 \\
\hline DLEXPORT $=-0.36 \mathrm{ECT}_{-1}$ & -0.14 DEXPORT $_{-1}$ & -1.14 DLREER_1 & +0.61 DFY_1 $_{-1}$ & $(00663)$ \\
\hline$(0.0972)$ & $(0.1204)$ & $(1.1463)$ & $(3.0429)$ & {$[0.7370]$} \\
\hline
\end{tabular}

Source: EVIEWS output. Note: ( ) represent standard error values, while [ ] represent T-Statistic values.

Table 10. Serial correlation (robustness).

\begin{tabular}{ccc}
\hline Lags & LM-Stat & Prob \\
\hline 1 & 16.61409 & 0.0551 \\
2 & 28.79572 & 0.0007 \\
\hline
\end{tabular}

Source: EVIEWS output.

Table 11. Heteroskedasticity test outcome for model 3 (robustness).

\begin{tabular}{cccc}
\hline & & & \\
\hline Joint test: & Df & Prob. \\
\hline 62.90711 & 48 & 0.0730 \\
\hline
\end{tabular}

Source: EVIEWS output.

shock response of LTBAL to LREER). On the whole, the outcome proved to exhibit satisfactory explanatory power as reflected in the R-Squared and the F-statistics, which also confirmed that the independent variables are jointly significant in explaining the dependent variable(s). With reference to the objectives, we also tested the outcome of the theoretical concept of the Absorption and Elasticity approaches, which also attested to satisfying the Marshall-Lerner condition (as reflected in Models 2 and 3). This was proved by taking up the absolute sum of the long-run price elasticity of Import and Export as illustrated here and also reference in Equation (1) (LExport + LImport $\geq 1$ ), implicitly expressed here as $[(-2.91)+(-1.78)=4.37]$.

The long-run outcome shows that Trade Balance in Sierra Leone is highly responsive to Broad Money (M2) as indicated in Model 1, which means that a one percent increase in Broad Money will be reciprocated by a reasonable amount of increase in Trade Balance level for the Sierra Leone economy. Conversely, the outcome seems quite different for the Import Model, where a percentage increase in Broad Money would reduce import by a reasonable amount, which is good for Sierra Leone, particularly in capacitating domestic production to support consumers' switching habit formation.

In the short run, despite the significant speed of adjustment coefficient for the 
Trade Balance model, there is mixed outcome with evidence showing that a percentage change in REER and Foreign Income could result in trade deficit, with the opposite occurring in the case of Trade Balance when Broad Money is increased by a percentage value.

The findings of this study is a worthwhile venture for policy recommendations, particularly in addressing mismatch connected with the Marshall-Lerner condition, which is not reflected very well in raising the country's trade balance profile as observed in Model 1. In that vein, effort should be pursued to boost real sector activities, with the intention of making it worthwhile for consumers to switch their habit formation towards domestically produced goods and services in the long-run.

Effort should be made to boost commodity exports, which will serve as catalyst for easing exchange rate problems in the Sierra Leone economy. Equally on this note, policy measures should be directed at diversifying the country's export base in a bid to reduce vulnerability in the event of shocks as witnessed more lately with the emergence of COVID-19 pandemic (see Jackson, 2020b). Effort should be stepped up to synchronize both the fiscal and monetary conditions, particularly adjustment in government spending pattern towards strengthening domestic production, specifically inelastic goods and services. Effective policy measures should also be stepped up in monitoring rent-seeking privileges (e.g., tax subsidy) accorded to businesses for the good of nation building, while at the same time expanding domestic productivity. This must be supported by efficient policy measures akin to Import Substitution Industrialisation (ISI) model, which is capable of capacitating high level of domestic productivity, preferably for inelastic goods and services (Jabbie \& Saffa, 2021; Jackson \& Jabbie, 2020b).

In future, study of this nature will benefit from a review of REER computation and also, the identification of potential trading partners with Sierra Leone in a bid to make it worthwhile to improve the study outcome, which is very relevant for effective policy implementation in the country's trade balance and exchange rate stability. Furthermore, the issue of structural breaks can be pronounced for developing economies' variables on account of regime change, conflict and policy shift; hence, a study incorporating specific tests that takes account of structural breaks will be useful going forward.

\section{Acknowledgements}

At this juncture, we wish to express appreciation to the following staff in the Research Department: Mr. Morlai Bangura (Director), Mr. Thomas Boima (Assistant Director, Monetary Policy Division) and Mr. Sandy Pessima (Manager, Monetary Policy Division) for their constructive feedback on technical concepts pertaining to the work. In addition, we also express appreciation to Mr. Rashid Koroma (Manager Balance of Payment Section) and his team for availing relevant dataset, which enabled us to accomplish the empirical estimation. Last but not least, our sincere appreciation also goes to the anonymous reviewers and also, Ms. 
Margaret Decker (BSL Librarian) who made it possible for us to access information pertaining to relevant documents and economic journal articles.

\section{Disclaimer}

Views expressed in this paper are those of the authors and do not reflect any of the named institutions to which they are associated.

\section{Conflicts of Interest}

The authors declare no conflicts of interest regarding the publication of this paper.

\section{References}

Adamu, P. A., \& Itsede, O. C. (2010). Balance of Payment Adjustment: The West African Monetary Zone Experience. Journal of Monetary and Economic Integration, 10, 100-116.

Adeniyi, O., Omisakin, O., \& Oyinola, A. (2011). Exchange Rate and Trade Balance in West African Monetary Zone: Is There a J-Curve? The International Journal of Applied Economics and Finance, 5, 167-176. https://doi.org/10.3923/ijaef.2011.167.176

Akbostanci, E. (2004). Dynamics of the Trade Balance: The Turkish J-Curve. Emerging Markets Finance and Trade, 40, 57-73. https://doi.org/10.1080/1540496X.2004.11052584

Alexander, S. (1952). Effects of Devaluation on a Trade Balance. IMF Staff Papers, 2, 263-278. https://doi.org/10.2307/3866218

Baba, A. K., \& Yazici, M. (2016). The j-Curve Hypothesis: An Investigation of Biletral Trade between Nigeria and European Union. Journal of International and Global Economic Studies, 9, 46-74.

Bahmani-Oskooee, M. (1985). Devaluation and the J-Curve: Some Evidence from LDCs. The Review of Economics and Statistics, 67, 500-504. https://doi.org/10.2307/1925980

Bahmani-Oskooee, M., \& Brooks, T. J. (1999). Bilateral J-Curve between U.S. and Her Trading Partners. Weltwirtschaftliches Archiv, 135, 156-165.

https://doi.org/10.1007/BF02708163

Bahmani-Oskooee, M., \& Durnaz, N. (2016). Asymmetric Cointegration and the J-Curve: Evidence from Commodity Trade between Turkey and EU. MPAR, No. 83183. https://mpra.ub.uni-muenchen.de/83183

Bahmani-Oskooee, M., Usman, A., \& Ullah, S. (2019). Asymmetric J-Curve in the Commodity Trade between Pakistan and United States: Evidence from 41 Industries. Eurasia Business and Economic Society, 10, 163-188. https://doi.org/10.1007/s40822-019-00137-x

Bangura, M., Caulker, E., \& Pessima, S. (2012). Exchange Rate Pass-Through to Inflation in Sierra Leone: A Structural Vector Autoregressive Approach. Journal of Monetary and Economic Integration, 12, 93-123.

Bangura, M., Denison-George, C., \& Caulker, R. (2013). The Impact of Exchange Rate Dynamics on the Trade Balance in Sierra Leone: An ARDL Cointegration Approach. Journal of Monetary and Economic Integration, 13, 64-88.

Bawa, S., Abdul, R. M., Sani, Z., \& Dauda, M. (2018). Testing the J-Curve Phenomenon in Nigeria: An ARDL Bounds Testing Approach. West African Journal of Monetary and Economic Integration, 18, 47-71.

Chen, J., Dong, W., Tong, J. Y., \& Zhang, F. F. (2018). Corporate Philanthropy and In- 
vestment Efficiency: Empirical Evidence from China. Pacific-Basin Finance Journal, 51, 392-409. https://doi.org/10.1016/j.pacfin.2018.08.008

Du Plessis, S. P. J., Smith, B. W., \& McCarthy, C. L. (1998). International Economics (2nd ed.). Heinemann.

Egbuna, N. E. (2018). Evolution of Monetary Integration: Case of the West African Monetary Zone. West African Journal of Monetary and Economic Integration, 18, 1-20. https://doi.org/10.5089/9781484352816.002

Englama, A., Sissoho, M., Odeniran, O., \& Haffner, O. (2019). Is Currency Devaluation Appropriate for Improving Trade Balance in the WAMZ Countries? In D. Seck (Ed.), The External Sector of African Economy (pp. 185-212). Advances in African Economic, Social and Political Development, Springer.

https://doi.org/10.1007/978-3-319-97913-7 9

George, A. A., \& Choi, H. (2019). The Dynamics of the US Trade Balance and Real Exchange Rate: The J-Curve and Trade Cost. National Bureau of Economic Research, Working Paper 25563.

Goldstein, M., \& Khan, M. S. (1985). Income and Price Effects in Foreign Trade. In R. W. Jones, \& P. B. Kenen (Eds.), Handbook of International Economics (vol. 2, pp. 1041-1105). North-Holland. https://doi.org/10.1016/S1573-4404(85)02011-1

Greenwood, J. (1984). Non-Traded Goods, the Trade Balance, and the Balance of Payments. Canadian Journal of Economics, 17, 806-923. https://doi.org/10.2307/135075

Harberger, A. (1950). Currency Depreciation, Income, and the Balance of Trade. Journal of Political Economy, 59, 47-60. https://doi.org/10.1086/256897

Hunter, A. (2019). Non-Linear Autoregressive Distributed Laag Model Approach and the J-Curve Phenomenon: China and Her Major Trading Partners. Major Themes in Economics, 21, 1-3. https://scholarworks.uni.edu/mtie/vol21/iss1/3

IGM Forum (2014). Trade Balance. http://www.igmchicago.org/surveys/trade-balances

Iyke, B. N., \& Ho, S.-Y. (2017). The Real Exchange Rate, the Ghanaian Trade Balance and the J-Curve. MPRA, Paper No. 78211. https://doi.org/10.1080/15228916.2017.1315706

Jabbie, M., \& Saffa, M. (2021). Functional Performance: A Sustainable Approach to Economic Optimality. In F. W. Leal, A. M. Azul, L. Brandli, A. Lange Salvia, \& T. Wall (Eds.), Industry, Innovation and Infrastructure. Encyclopaedia of the UN Sustainable Development Goals. Springer. https://doi.org/10.1007/978-3-319-95873-6 19

Jackson, E. A. (2020a). Understanding SLL/US\$ Exchange Rate Dynamics in Sierra Leone Using Box-Jenkins ARIMA Approach. Theoretical and Practical Research in the Economic Fields, 11, 5-20. https://doi.org/10.2139/ssrn.3518233

Jackson, E. A. (2020b). Emerging Innovative thoughts on Globalization amidst the Contagion of COVID-19. In F. W. Leal, A. M. Azul, L. Brandli, A. Lange Salvia, \& T. Wall (Eds.), Industry, Innovation and Infrastructure. Encyclopedia of the UN Sustainable Development Goals. Springer. https://doi.org/10.1007/978-3-319-71059-4 131-1

Jackson, E. A., \& Jabbie M. (2019). Understanding Market Failure in the Developing Country Context. In W. Leal Filho, A. Azul, L. Brandli, P. Özuyar, \& T. Wall (Eds.), Decent Work and Economic Growth. Encyclopedia of the UN Sustainable Development Goals. (Online) Springer, Cham. https://doi.org/10.1007/978-3-319-71058-7 44-1

Jackson, E. A., \& Jabbie, M. (2020a). Twin Deficits Hypothesis as an Indication of Government Failure in Sierra Leone: An Empirical Investigation (1980-2018). Journal of Economic Policy Researches, 7, 43-68. https://doi.org/10.26650/JEPR658440

Jackson, E. A., Jabbie, M., Tamuke, E., \& Ngombu, A. (2020). Adoption of Inflation Targeting in Sierra Leone: Empirical Discourse. Journal of Economic Policy Researches, 7, 
$1-32$.

Jackson, E. A., \& Jabbie, M. (2020b). Import Substitution Industrialization (ISI): An Approach to Global Economic Sustainability. In F. W. Leal, A. M. Azul, L. Brandli, A. Lange Salvia, \& T. Wall (Eds.), Industry, Innovation and Infrastructure. Encyclopedia of the UN Sustainable Development Goals. Springer. https://doi.org/10.1007/978-3-319-95873-6 116

Kulkarni, K. (2007). Readings in International Economics. Serials Publications.

Kulkarni, K., \& Clarke, A. (2009). Testing the j-Curve Hypothesis: Studies from around the World (pp. 1-32). International Economics Practicum.

Lerner, A. (1944). Economics of Control: Principle of Welfare Economics. Macmillan.

Meade, J. (1951). The Balance of Payments. Oxford University Press.

Ogundipe, A. A., Ojeaga, P., Oluwatomsin, M., \& Ogundipe, N. (2013). Estimating the Long Run Effects of Exchange Rate Devaluation on the Trade Balance of Nigeria. European Scientific Journal, 9, 233-249.

Onafowora, O. (2003). Exchange Rate and Trade Balance in East Asia: Is There a J-Curve? Economics Bulletin, 5, 1-13.

Onakoya, A. B., \& Johnson, S. B. (2018). Exchange Rate and Trade Balance: The Case for J-Curve Effect in Nigeria. KIU Journal of Social Sciences, 4, 47-63.

Pinto, B. (1988). Black Market Premia, Exchange Rate Unification, and Inflation in Sub-Saharan Africa. World Development Report, Policy, Planning and Research Working Papers, WPS 37.

http://documents.worldbank.org/curated/en/349551468767398366/pdf/multi-page.pdf

Robinson, J. (1947). The Foreign Exchanges. In J. Robinson (Ed.), Essay in the Theory of Employent (pp. 134-155). Basil Blackwell.

Rose, A. K., \& Yellen, J. L. (1989). Is There a J-Curve? Journal of Monetary Economics, 24, 53-68. https://doi.org/10.1016/0304-3932(89)90016-0

Sani, B., Rabia, M. A., Sani, Z., \& Dauda, M. (2018). Testing the J-Curve Phenomenon in Nigeria: An ARDL Bounds Testing Approach. West African Journal of Monetary and Economic Integration, 18, 47-71.

Schaling, E., \& Kabundi, A. (2014). The Exchange Rate, the Trade Balance and the J-Curve Effect in South Africa. SAJEMS, 17, 601-608. https://doi.org/10.4102/sajems.v17i5.727

SSL Statistics Sierra Leone (2014). Report on the 2013 Real Gross Domestic Product (RGDP) Figures at 2006 Prices and the Impact of Ebola Virus Disease (EVD) on the 2014 GDP Projections.

https://www.statistics.sl/images/StatisticsSL/Documents/gdp/2013 2014 gdp analysis. pdf

Tamuke, E., Jackson, E. A., \& Sillah, A. (2018). Forecasting Inflation in Sierra Leone Using ARIMIA and ARIMAX: A Comparative Evaluation. Theoretical and Practical Research in Economic Field, 9, 63-74.

Warburton, C. E. S., \& Jackson, E. A. (2020). Monetary Policy Responses to Exogenous Perturbations: The Case of a Small Open Economy (2007-2018). PSL Quarterly Review, 73, 181-201. https://doi.org/10.13133/2037-3643 73.293 5

Wilson, P., \& Tat, K. C. (2001). Exchange Rate and the Trade Balance: The Case of Singapore 1971-1996. Journal of Asian Economics, 12, 47-63.

https://doi.org/10.1016/S1049-0078(01)00072-0 


\section{Appendices}

Note: All information in the Appendices was sourced from EVIEWS estimation.

\section{Appendix 1: Unit Root Test Outcomes}

All of the Unit Root test outcomes below represent the MacKinnon (996) one-sided p-values.

\begin{tabular}{|c|c|c|c|}
\hline \multicolumn{4}{|c|}{ Null Hypothesis: D (LTBAL) has a unit root } \\
\hline \multicolumn{2}{|c|}{ Phillips-Perron test statistic } & Adj. $t$-Stat & Prob.* \\
\hline & & -14.97135 & 0.0000 \\
\hline \multirow[t]{3}{*}{ Test critical values: } & $1 \%$ level & -2.597939 & \\
\hline & $5 \%$ level & -1.945456 & \\
\hline & $10 \%$ level & -1.613799 & \\
\hline \multicolumn{4}{|c|}{ Null Hypothesis: D (LREER) has a unit root } \\
\hline \multicolumn{2}{|c|}{ Phillips-Perron test statistic } & Adj. t-Stat & Prob.* \\
\hline \multirow{4}{*}{ Test critical values: } & & -6.556816 & 0.0000 \\
\hline & $1 \%$ level & -2.597939 & \\
\hline & $5 \%$ level & -1.945456 & \\
\hline & $10 \%$ level & -1.613799 & \\
\hline
\end{tabular}

Null Hypothesis: D (LM2) has a unit root

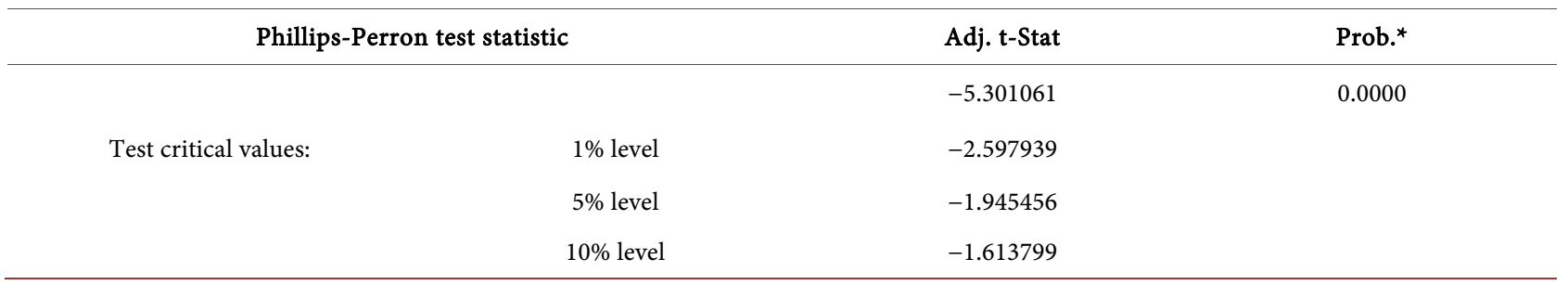

\section{Null Hypothesis: D (LDY) has a unit root}

\begin{tabular}{|c|c|c|c|}
\hline \multicolumn{2}{|c|}{ Phillips-Perron test statistic } & $\begin{array}{c}\text { Adj. t-Stat } \\
-8.652950\end{array}$ & $\begin{array}{l}\text { Prob. }^{*} \\
0.0000\end{array}$ \\
\hline \multirow[t]{3}{*}{ Test critical values: } & $1 \%$ level & -2.597939 & \\
\hline & $5 \%$ level & -1.945456 & \\
\hline & $10 \%$ level & -1.613799 & \\
\hline
\end{tabular}

\section{Null Hypothesis: D (LFY) has a unit root}

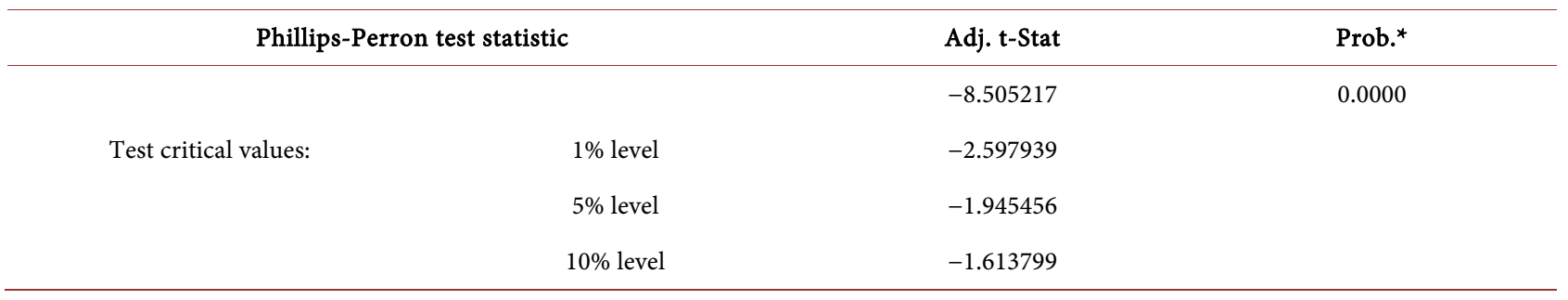




\section{Appendix 2: Lag Length Selection}

VAR Lag Order Selection Criteria

Endogenous variables: LFY LDY LM2 LREER LTBAL

Exogenous variables: $\mathrm{C}$

Date: 03/05/20 Time: 18:11

Sample: 2001Q4 2019Q4

Included observations: 67

\begin{tabular}{ccccccc}
\hline Lag & LogL & LR & FPE & AIC & SC & HQ \\
\hline 0 & 96.41028 & NA & $4.49 \mathrm{e}-08$ & -2.728665 & -2.564136 & -2.663561 \\
1 & 484.4681 & 706.6127 & $8.85 \mathrm{e}-13$ & -13.56621 & $-12.57904^{*}$ & $-13.17558^{*}$ \\
2 & 506.7729 & 37.28562 & $9.71 \mathrm{e}-13$ & -13.48576 & -11.67593 & -12.76961 \\
3 & 530.9008 & 36.73209 & $1.03 \mathrm{e}-12$ & -13.45973 & -10.82726 & -12.41805 \\
4 & 555.6699 & 34.01129 & $1.10 \mathrm{e}-12$ & -13.45283 & -9.997718 & -12.08564 \\
5 & 621.5958 & $80.68543^{*}$ & $3.61 \mathrm{e}-13^{*}$ & $-14.67450^{*}$ & -10.39674 & -12.98178 \\
6 & 639.6843 & 19.43844 & $5.24 \mathrm{e}-13$ & -14.46819 & -9.367781 & -12.44995 \\
\hline
\end{tabular}

${ }^{*}$ indicates lag order selected by the criterion

LR: sequential modified LR test statistic (each test at 5\% level)

FPE: Final prediction error

AIC: Akaike information criterion

SC: Schwarz information criterion

HQ: Hannan-Quinn information criterion

\section{Appendix 3: Johansen Cointegration Test Results for Model 1}

\begin{tabular}{ccccc}
\hline & \multicolumn{4}{c}{ Unrestricted Cointegration Rank Test (Trace)-Series: LFY LM2 LREER LTBAL } \\
\hline Hypothesized & & Trace & 0.05 & Prob.** \\
\hline No. of CE(s) & Eigenvalue & Statistic & Critical Value & 0.0205 \\
\hline None* & 0.351543 & 51.75991 & 47.85613 & 0.3573 \\
At most 1 & 0.230461 & 21.00559 & 29.79707 & 0.9874 \\
At most 2 & 0.032422 & 2.406144 & 15.49471 & 0.7972 \\
At most 3 & 0.000929 & 0.066005 & 3.841466 & \\
\hline
\end{tabular}

Trace test indicates 1 cointegrating eqn(s) at the 0.05 level

${ }^{*}$ denotes rejection of the hypothesis at the 0.05 level

${ }^{* *}$ MacKinnon-Haug-Michelis (1999) p-values

\begin{tabular}{|c|c|c|c|c|}
\hline \multicolumn{5}{|c|}{ Unrestricted Cointegration Rank Test (Maximum Eigenvalue) } \\
\hline Hypothesized & & Max-Eigen & 0.05 & \\
\hline No. of $\mathrm{CE}(\mathrm{s})$ & Eigenvalue & Statistic & Critical Value & Prob.* ${ }^{* *}$ \\
\hline None $^{*}$ & 0.351543 & 30.75432 & 27.58434 & 0.0189 \\
\hline At most 1 & 0.230461 & 18.59945 & 21.13162 & 0.1090 \\
\hline At most 2 & 0.032422 & 2.340139 & 14.26460 & 0.9807 \\
\hline At most 3 & 0.000929 & 0.066005 & 3.841466 & 0.7972 \\
\hline
\end{tabular}

Max-eigenvalue test indicates 1 cointegrating eqn(s) at the 0.05 level

* denotes rejection of the hypothesis at the 0.05 level

${ }^{* *}$ MacKinnon-Haug-Michelis (1999) p-values 


\section{Appendix 4: VECM Output for TBAL Model}

\begin{tabular}{|c|c|c|c|c|}
\hline \multicolumn{5}{|c|}{ Vector Error Correction Estimates } \\
\hline \multicolumn{5}{|c|}{ Sample (adjusted): 2002Q2 2019Q4 } \\
\hline \multicolumn{5}{|c|}{ Included observations: 71 after adjustments } \\
\hline \multicolumn{5}{|c|}{ Standard errors in ( ) \& t-statistics in [ ] } \\
\hline Cointegrating Eq: & CointEq1 & & & \\
\hline $\operatorname{LTBAL}(-1)$ & 1.000000 & & & \\
\hline \multirow[t]{3}{*}{$\operatorname{LREER}(-1)$} & -1.115485 & & & \\
\hline & $(0.65059)$ & & & \\
\hline & {$[-1.71458]$} & & & \\
\hline \multirow[t]{3}{*}{$\operatorname{LM} 2(-1)$} & 1.569845 & & & \\
\hline & $(0.57332)$ & & & \\
\hline & {$[2.73819]$} & & & \\
\hline \multirow[t]{3}{*}{$\operatorname{LFY}(-1)$} & -6.420455 & & & \\
\hline & $(2.50730)$ & & & \\
\hline & {$[-2.56071]$} & & & \\
\hline $\mathrm{C}$ & 45.35606 & & & \\
\hline Error Correction: & $\mathrm{D}(\mathrm{LTBAL})$ & $\mathrm{D}$ (LREER) & $\mathrm{D}(\mathrm{LM} 2)$ & $\mathrm{D}(\mathrm{LFY})$ \\
\hline \multirow[t]{3}{*}{ CointEq1 } & -0.734949 & 0.021449 & 0.004850 & 0.009431 \\
\hline & $(0.14252)$ & $(0.01454)$ & $(0.01234)$ & $(0.00454)$ \\
\hline & {$[-5.15680]$} & {$[1.47497]$} & {$[0.39306]$} & {$[2.07895]$} \\
\hline \multirow[t]{3}{*}{$\mathrm{D}(\operatorname{LTBAL}(-1))$} & -0.005552 & -0.008769 & -0.005252 & 0.002223 \\
\hline & $(0.12567)$ & $(0.01282)$ & $(0.01088)$ & $(0.00400)$ \\
\hline & {$[-0.04418]$} & {$[-0.68386]$} & {$[-0.48279]$} & {$[0.55574]$} \\
\hline \multirow[t]{3}{*}{$\mathrm{D}(\operatorname{LREER}(-1))$} & -2.383506 & 0.191148 & -0.046135 & -0.065171 \\
\hline & $(1.14966)$ & $(0.11730)$ & $(0.09953)$ & $(0.03659)$ \\
\hline & {$[-2.07323]$} & [1.62953] & {$[-0.46354]$} & [-1.78089] \\
\hline \multirow[t]{3}{*}{$\mathrm{D}(\mathrm{LM} 2(-1))$} & 1.457197 & -0.053368 & -0.294281 & 0.195558 \\
\hline & $(1.44071)$ & $(0.14700)$ & $(0.12472)$ & $(0.04586)$ \\
\hline & {$[1.01144]$} & {$[-0.36305]$} & {$[-2.35948]$} & {$[4.26433]$} \\
\hline \multirow[t]{2}{*}{$\mathrm{D}(\operatorname{LFY}(-1))$} & -3.629796 & 0.538029 & -0.448152 & -0.140672 \\
\hline & $(3.11178)$ & $(0.31750)$ & $(0.26939)$ & $(0.09905)$ \\
\hline
\end{tabular}




\section{Continued}

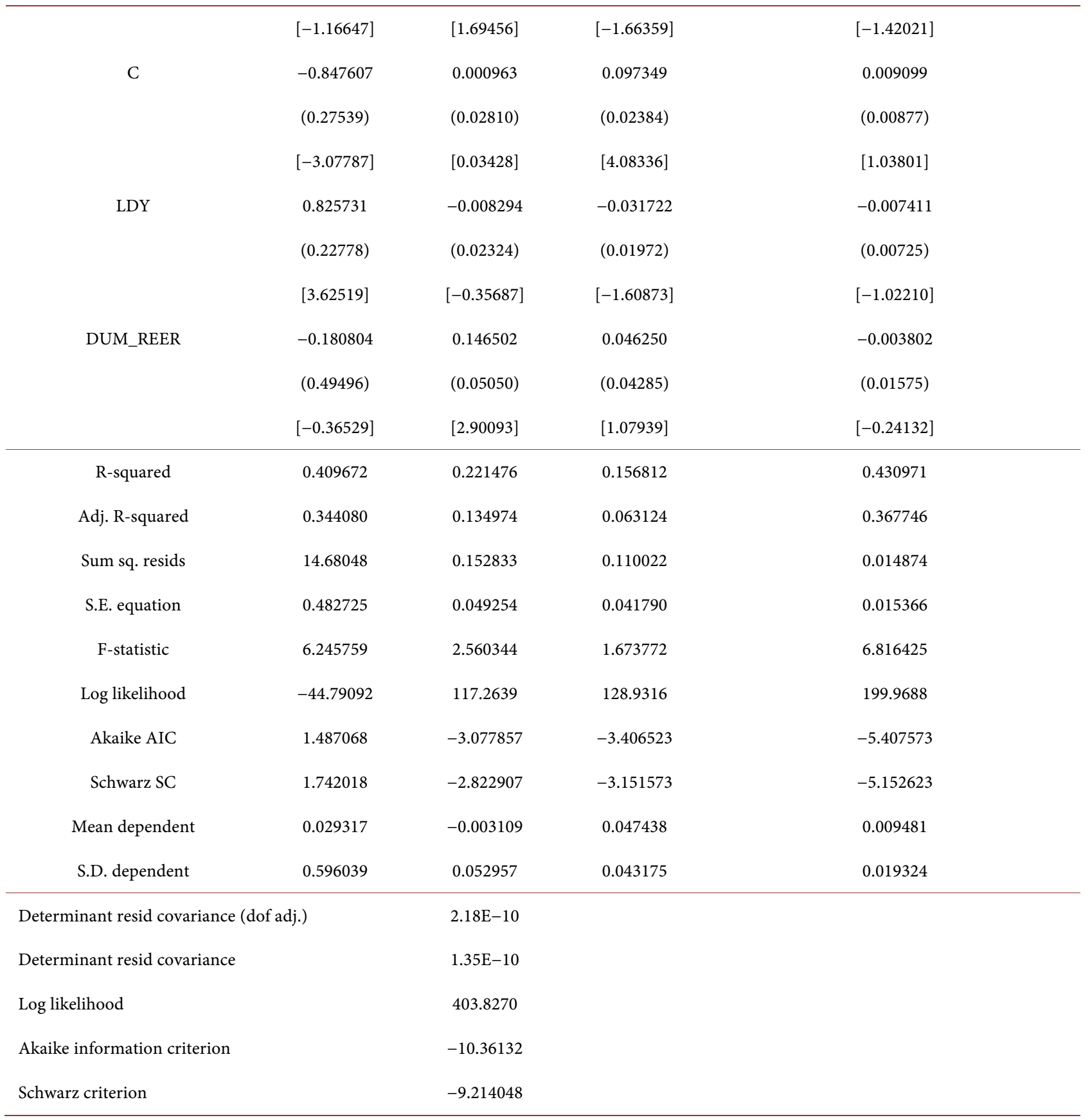




\section{Appendix 5: VECM Outcome for Import Model}

\begin{tabular}{|c|c|c|c|c|}
\hline \multicolumn{5}{|c|}{ Vector Error Correction Estimates } \\
\hline \multicolumn{5}{|l|}{ Date: 04/18/20 Time: 19:04 } \\
\hline \multicolumn{5}{|c|}{ Sample (adjusted): 2002Q2 2019Q4 } \\
\hline \multicolumn{5}{|c|}{ Included observations: 71 after adjustments } \\
\hline \multicolumn{5}{|c|}{ Standard errors in ( ) \& t-statistics in [ ] } \\
\hline Cointegrating Eq: & CointEq1 & & & \\
\hline $\operatorname{LIMPORT}(-1)$ & 1.000000 & & & \\
\hline \multirow[t]{3}{*}{$\operatorname{LREER}(-1)$} & -1.787913 & & & \\
\hline & $(0.54289)$ & & & \\
\hline & {$[-3.29331]$} & & & \\
\hline \multirow[t]{3}{*}{$\operatorname{LDY}(-1)$} & 0.047492 & & & \\
\hline & $(0.50101)$ & & & \\
\hline & [0.09479] & & & \\
\hline \multirow{3}{*}{$\operatorname{LM} 2(-1)$} & -0.635238 & & & \\
\hline & $(0.20508)$ & & & \\
\hline & {$[-3.09749]$} & & & \\
\hline $\mathrm{C}$ & 6.435702 & & & \\
\hline Error Correction: & $\mathrm{D}($ LIMPORT) & D(LREER) & $\mathrm{D}(\mathrm{LDY})$ & $\mathrm{D}(\mathrm{LM} 2)$ \\
\hline \multirow[t]{3}{*}{ CointEq1 } & -0.342010 & 0.035194 & 0.043874 & 0.040184 \\
\hline & $(0.10128)$ & $(0.01707)$ & $(0.01974)$ & $(0.01366)$ \\
\hline & {$[-3.37682]$} & {$[2.06184]$} & {$[2.22282]$} & {$[2.94188]$} \\
\hline \multirow[t]{3}{*}{ D(LIMPORT(-1)) } & 0.022802 & 0.006214 & -0.023639 & -0.032783 \\
\hline & $(0.13055)$ & $(0.02200)$ & $(0.02544)$ & $(0.01761)$ \\
\hline & {$[0.17466]$} & {$[0.28243]$} & {$[-0.92917]$} & {$[-1.86201]$} \\
\hline \multirow[t]{3}{*}{$\mathrm{D}(\operatorname{LREER}(-1))$} & 0.239305 & 0.213334 & -0.031224 & -0.092534 \\
\hline & $(0.68682)$ & $(0.11575)$ & $(0.13385)$ & $(0.09263)$ \\
\hline & {$[0.34842]$} & {$[1.84304]$} & {$[-0.23328]$} & {$[-0.99897]$} \\
\hline \multirow[t]{3}{*}{$\mathrm{D}(\operatorname{LDY}(-1))$} & 1.635357 & 0.055214 & -0.110985 & -0.167292 \\
\hline & $(0.58664)$ & $(0.09887)$ & $(0.11433)$ & $(0.07912)$ \\
\hline & [2.78766] & {$[0.55846]$} & {$[-0.97077]$} & {$[-2.11447]$} \\
\hline \multirow[t]{2}{*}{$\mathrm{D}(\mathrm{LM} 2(-1))$} & 0.906753 & -0.082699 & 0.416358 & -0.271193 \\
\hline & $(0.85511)$ & $(0.14411)$ & $(0.16665)$ & $(0.11532)$ \\
\hline
\end{tabular}


E. A. Jackson et al.

\section{Continued}

\begin{tabular}{|c|c|c|c|c|}
\hline \multirow{4}{*}{$\mathrm{C}$} & [1.06040] & {$[-0.57385]$} & [2.49846] & {$[-2.35157]$} \\
\hline & -0.051662 & $3.97 \mathrm{E}-05$ & 0.000373 & 0.064258 \\
\hline & $(0.05703)$ & $(0.00961)$ & $(0.01112)$ & $(0.00769)$ \\
\hline & {$[-0.90580]$} & {$[0.00413]$} & {$[0.03356]$} & [8.35382] \\
\hline R-squared & 0.223433 & 0.150004 & 0.175683 & 0.181064 \\
\hline Adj. R-squared & 0.163698 & 0.084619 & 0.112274 & 0.118069 \\
\hline Sum sq. resids & 5.874933 & 0.166864 & 0.223128 & 0.106858 \\
\hline S.E. equation & 0.300639 & 0.050667 & 0.058590 & 0.040546 \\
\hline F-statistic & 3.740356 & 2.294183 & 2.770640 & 2.874266 \\
\hline Log likelihood & -12.27916 & 114.1459 & 103.8309 & 129.9676 \\
\hline Akaike AIC & 0.514906 & -3.046362 & -2.755799 & -3.492046 \\
\hline Schwarz SC & 0.706118 & -2.855150 & -2.564586 & -3.300833 \\
\hline Mean dependent & 0.022566 & -0.003109 & 0.017167 & 0.047438 \\
\hline S.D. dependent & 0.328748 & 0.052957 & 0.062184 & 0.043175 \\
\hline Determinant resid covari & & $1.25 \mathrm{E}-09$ & & \\
\hline Determinant resid covari & & $8.79 \mathrm{E}-10$ & & \\
\hline Log likelihood & & 337.2759 & & \\
\hline Akaike information criter & & -8.711998 & & \\
\hline Schwarz criterion & & -7.819674 & & \\
\hline
\end{tabular}




\section{Appendix 6: VECM Output for Export Model}

\begin{tabular}{|c|c|c|c|}
\hline \multicolumn{4}{|l|}{ Vector Error Correction Estimates } \\
\hline \multicolumn{4}{|l|}{ Sample (adjusted): 2002Q2 2019Q4 } \\
\hline \multicolumn{4}{|c|}{ Included observations: 71 after adjustments } \\
\hline \multicolumn{4}{|c|}{ Standard errors in ( ) \& t-statistics in [ ] } \\
\hline Cointegrating Eq: & CointEq1 & & \\
\hline $\operatorname{LEXPORT}(-1)$ & 1.000000 & & \\
\hline \multirow[t]{3}{*}{$\operatorname{LREER}(-1)$} & -2.911887 & & \\
\hline & $(0.93381)$ & & \\
\hline & {$[-3.11828]$} & & \\
\hline \multirow[t]{3}{*}{$\operatorname{LFY}(-1)$} & -2.473156 & & \\
\hline & $(0.69204)$ & & \\
\hline & {$[-3.57372]$} & & \\
\hline C & 27.29460 & & \\
\hline Error Correction: & $\mathrm{D}(\mathrm{LEXPORT})$ & D(LREER) & $\mathrm{D}(\mathrm{LFY})$ \\
\hline \multirow[t]{3}{*}{ CointEq1 } & -0.359564 & 0.030042 & 0.004976 \\
\hline & $(0.09723)$ & $(0.00954)$ & $(0.00355)$ \\
\hline & {$[-3.69809]$} & {$[3.14904]$} & {$[1.40148]$} \\
\hline \multirow[t]{3}{*}{$\mathrm{D}(\operatorname{LEXPORT}(-1))$} & -0.144822 & -0.005945 & 0.003872 \\
\hline & $(0.12040)$ & $(0.01181)$ & $(0.00440)$ \\
\hline & {$[-1.20281]$} & {$[-0.50321]$} & {$[0.88071]$} \\
\hline \multirow[t]{3}{*}{ D(LREER $(-1))$} & -1.137686 & 0.227148 & -0.075116 \\
\hline & (1.14628) & $(0.11247)$ & $(0.04186)$ \\
\hline & {$[-0.99250]$} & [2.01959] & {$[-1.79452]$} \\
\hline \multirow[t]{3}{*}{$\mathrm{D}(\operatorname{LFY}(-1))$} & 0.607158 & 0.441923 & -0.266193 \\
\hline & $(3.04291)$ & $(0.29857)$ & $(0.11112)$ \\
\hline & [0.19953] & {$[1.48014]$} & {$[-2.39559]$} \\
\hline \multirow[t]{3}{*}{$\mathrm{C}$} & 0.048839 & -0.006722 & 0.011794 \\
\hline & $(0.06627)$ & $(0.00650)$ & $(0.00242)$ \\
\hline & [0.73699] & {$[-1.03386]$} & [4.87380] \\
\hline R-squared & 0.255386 & 0.209323 & 0.177523 \\
\hline Adj. R-squared & 0.210258 & 0.161403 & 0.127676 \\
\hline Sum sq. resids & 16.12256 & 0.155219 & 0.021499 \\
\hline S.E. equation & 0.494248 & 0.048495 & 0.018048 \\
\hline F-statistic & 5.659135 & 4.368185 & 3.561342 \\
\hline Log likelihood & -48.11729 & 116.7140 & 186.8910 \\
\hline Akaike AIC & 1.496262 & -3.146873 & -5.123690 \\
\hline
\end{tabular}


E. A. Jackson et al.

\section{Continued}

\begin{tabular}{|c|c|c|c|}
\hline Schwarz SC & 1.655605 & -2.987530 & -4.964346 \\
\hline Mean dependent & 0.051883 & -0.003109 & 0.009481 \\
\hline S.D. dependent & 0.556163 & 0.052957 & 0.019324 \\
\hline Determinant resid covariance (dof adj.) & & $1.84 \mathrm{E}-07$ & \\
\hline Determinant resid covariance & & $1.48 \mathrm{E}-07$ & \\
\hline Log likelihood & & 256.1185 & \\
\hline Akaike information criterion & & -6.707564 & \\
\hline Schwarz criterion & & -6.133927 & \\
\hline
\end{tabular}

\section{Appendix 7: Summary Statistics}

\begin{tabular}{|c|c|c|c|c|c|c|c|}
\hline & LDY & LEXPORT & LIMPORT & LFY & LREER & LM2 & LTBAL \\
\hline Mean & 1.007730 & 10.23329 & 11.07983 & 9.650548 & 4.689232 & 14.45626 & -0.846537 \\
\hline Maximum & 1.610837 & 12.19597 & 12.27447 & 9.972988 & 4.990841 & 15.95945 & 0.533276 \\
\hline Minimum & 0.223144 & 7.648644 & 9.857391 & 9.299857 & 4.436988 & 12.59137 & -2.420743 \\
\hline Std. Dev. & 0.446390 & 0.941496 & 0.717319 & 0.191419 & 0.140010 & 1.027877 & 0.552061 \\
\hline Skewness & -0.333316 & -0.204250 & -0.131785 & -0.099834 & 0.425921 & -0.233661 & -0.040301 \\
\hline Kurtosis & 1.784458 & 2.896201 & 1.581619 & 2.133609 & 1.929592 & 1.734110 & 3.170010 \\
\hline Jarque-Bera & 5.765825 & 0.532940 & 6.243824 & 2.371503 & 5.614219 & 5.462603 & 0.106200 \\
\hline Sum & 72.55657 & 736.7972 & 797.7478 & 694.8395 & 337.6247 & 1040.851 & -60.95065 \\
\hline Sum Sq. Dev. & 14.14774 & 62.93549 & 36.53279 & 2.601531 & 1.391808 & 75.01376 & 21.63873 \\
\hline Observations & 72 & 72 & 72 & 72 & 72 & 72 & 72 \\
\hline
\end{tabular}

